
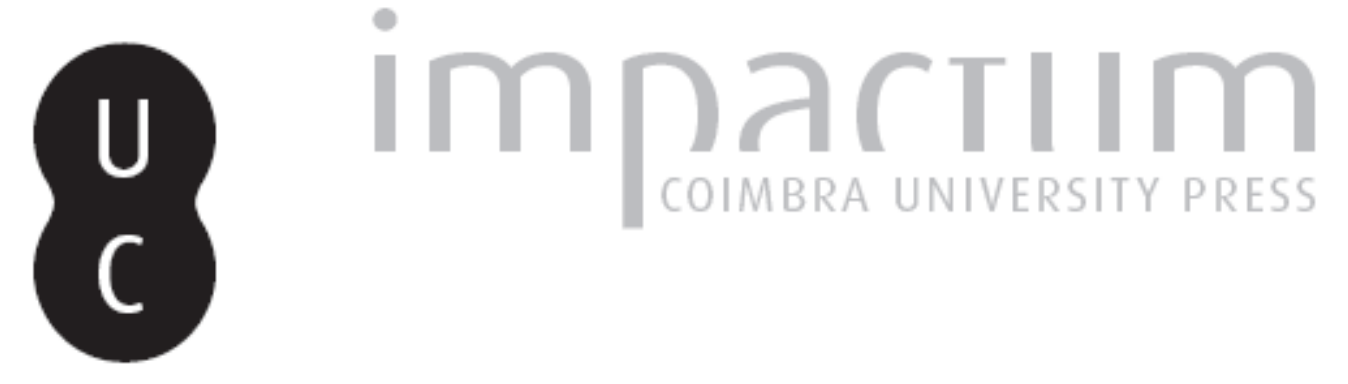

\title{
Risco e crise nas inundações rápidas em espaço urbano: alguns exemplos portugueses analisados a diferentes escalas
}

\author{
Autor(es): $\quad$ Rebelo, Fernando \\ Publicado por: Associação Portuguesa de Riscos, Prevenção e Segurança \\ URL \\ persistente: \\ URI:http://hdl.handle.net/10316.2/40145 \\ DOI: \\ DOI:https://doi.org/10.14195/1647-7723_4_4 \\ Accessed : $\quad$ 26-Apr-2023 14:29:02
}

A navegação consulta e descarregamento dos títulos inseridos nas Bibliotecas Digitais UC Digitalis, UC Pombalina e UC Impactum, pressupõem a aceitação plena e sem reservas dos Termos e Condições de Uso destas Bibliotecas Digitais, disponíveis em https://digitalis.uc.pt/pt-pt/termos.

Conforme exposto nos referidos Termos e Condições de Uso, o descarregamento de títulos de acesso restrito requer uma licença válida de autorização devendo o utilizador aceder ao(s) documento(s) a partir de um endereço de IP da instituição detentora da supramencionada licença.

Ao utilizador é apenas permitido o descarregamento para uso pessoal, pelo que o emprego do(s) título(s) descarregado(s) para outro fim, designadamente comercial, carece de autorização do respetivo autor ou editor da obra.

Na medida em que todas as obras da UC Digitalis se encontram protegidas pelo Código do Direito de Autor e Direitos Conexos e demais legislação aplicável, toda a cópia, parcial ou total, deste documento, nos casos em que é legalmente admitida, deverá conter ou fazer-se acompanhar por este aviso.

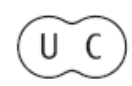




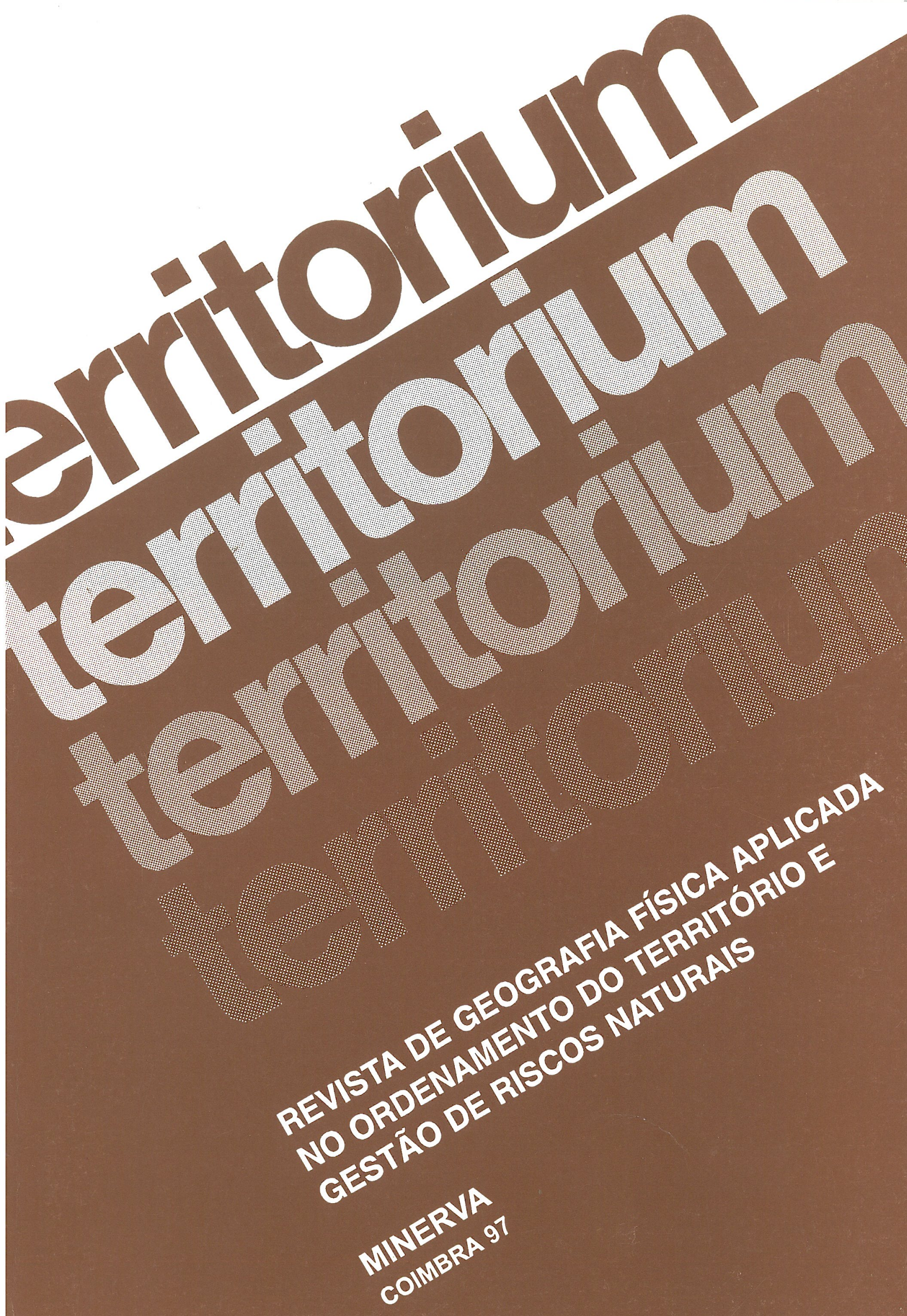




\title{
Risco e crise nas inundações rápidas em espaço urbano. Alguns exemplos portugueses analisados a diferentes escalas
}

\author{
Fernando Rebelo*
}

\begin{abstract}
Resumo:
Os riscos de inundações rápidas são bem conhecidos em áreas de clima mediterrâneo. Neste artigo, analisam-se exemplos de grandes catástrofes (região de Lisboa, Funchal e Povoação), tal como alguns casos de pequena dimensão escolhidos em Coimbra entre os muitos que se verificam em cidades e vilas portuguesas.

Palavras chave:

Riscos, chuvas intensas, inundações rápidas, Portugal.

Résumé:

Dans les régions méditerranéennes les inondations rapides sont des événements bien connus. Le présent article analyse quelques exemples d'inondations rapides catastrophiques (région de Lisbonne, Funchal et Povoação), ainsi que trois cas de petite dimension choisis à Coimbra entre beaucoup de cas enregistrés à l'intérieur des villes du Portugal.

Mots clés:

Risques, pluies intenses, inondations rapides, Portugal.

Abstract:

Flash floods are well known situations in the mediterranean regions. In this paper some examples of catastrophic flash floods (Lisbon region, Funchal and Povoação) are analysed, as well as three small scale case studies in Coimbra, chosen from a variety in portuguese towns.

Key kords:

Risks, intensive raining, flash floods, Portugal.
\end{abstract}

\section{Introdução}

A análise do risco de inundação rápida no interior das cidades é, indubitavelmente, uma das grandes preocupações do planeamento urbano. Para que seja desenvolvida com eficácia, essa análise deverá ter em conta não só as características naturais das áreas em estudo (características climáticas e hidrológicas, relacionando-se estas com as biogeográficas, morfológicas e geológicas), mas também as características da sua ocupação humana. Umas e outras, por vezes, interpenetram-se não se revelando sempre claramente separáveis.

Tal como no estudo de um qualquer outro risco, por exemplo, pensando particularmente no nosso país, no risco dos incêndios florestais (F. REBELO, 1995a), também aqui é importante conhecer casos concretos da sua manifestação, que, do mesmo modo, se apresentam a escalas muito diversas. Por um lado, podem tirar-se ilações de interesse para que, numa eventual repetição dos acontecimentos, se processem de modo mais eficiente as ajudas da Protecção Civil, seja em termos de preparação, ao nível dos primeiros sinais de perigo, seja em termos de socorro, no momento da crise; por outro lado, podem entenderse melhor as características dos elementos actuantes ao nível dos riscos, no sentido de fazer um trabalho eficaz de prevenção e de dar elementos fundamentais ao planeamento para, na medida do possível, se reduzirem as vulnerabilidades (L. FAUGERES, 1990; P. BLAIKIE et al., 1994). 
Esses momentos difíceis do desenvolvimento das crises são o tempo de actuação da Protecção Civil, mas têm sido também o tempo de análise e reflexão dos geógrafos que'se prolonga para além delas no estudo científico do acontecido. Hoje, com outras designações e com outros modelos (Quadro I) faz-se, no fundo, o que sempre se fez. Por isso, facilmente se conclui que a análise do risco, neste caso, climato-hidrológico, para uma qualquer área em estudo, baseando-se, embora, em conhecimentos mais ou menos teóricos, só ganha força quando há casos concretos de manifestação de crises.

Quadro I - Teoria do risco*

\begin{tabular}{cccc}
\hline \multicolumn{2}{c}{$\begin{array}{c}\text { Conceptualização } \\
\text { Sequência }\end{array}$} & \multicolumn{2}{c}{ Socialização } \\
\hline RISCO & $\begin{array}{c}\text { Sistema de } \\
\text { processos }\end{array}$ & $\begin{array}{c}\text { ANÁLISE } \\
\text { DO RISCO }\end{array}$ & $\begin{array}{c}\text { PROTECCCÁO CIVIL } \\
\text { e PLANEAMENTO }\end{array}$ \\
PERIGO & $\begin{array}{c}\text { Percepção } \\
\text { Reacções }\end{array}$ & $\begin{array}{c}\text { AVALIAĈ̃A } \\
\text { DO PERIGO }\end{array}$ & $\begin{array}{c}\text { PROTECCLÃO } \\
\text { CIVIL }\end{array}$ \\
CRISE & Manifestação & $\begin{array}{c}\text { GESTÃO } \\
\text { DA CRISE }\end{array}$ & \\
\hline
\end{tabular}

* Resumo elaborado a partir do modelo de L. FAUGÈRES (1990).

\section{Risco climático e risco hidrológico}

\section{Chuvas intensas}

Ao pensarmos em inundações rápidas (flash floods) temos de considerar, antes de mais, do ponto de vista natural, o risco climático. As inundações rápidas ligam-se quase sempre com a ocorrência de chuvas intensas, habituais sob certos tipos de climas e particularmente importantes em certas regiões.

Bem nossos conhecidos, pelas suas consequências, são os episódios de chuvas intensas nos países de clima temperado mediterrâneo. Lembramo-nos, facilmente, de situações de crise vividas na Itália (Orba), na França (Nîmes, Vaison La Romaine), na Espanha (Biescas), em Portugal (Lisboa, Funchal, Povoação). Algumas destas catástrofes ficaram célebres ou pelas quantidades de precipitação registada (Orba, na Sicília, com $554 \mathrm{~mm}$ em 8 horas, num dia de Agosto de 1933 - Ch. PÉGUY, 1970), ou pelo número de mortos ocasionado (mais de 500 em Lisboa, de 25 para 26 de Novembro de 1967$)^{(1)}$.

(1)Os números oficiais situaram-se por volta dos 360 mortos. Oito dias depois da tragédia, quando já não eram indicados mais números, ainda tivemos a triste oportunidade de ver desenterrar cadáveres da lama na Praça de Algés; além disso, foi do conhecimento público que vários automóveis com pessoas foram levados para o Tejo ou mesmo directamente para o mar. Quando, como muitas vezes acontece, se fala em 400 mortos, trata-se de uma estimativa que, quanto a nós, peca por defeito. Quando, na época, se chegou a falar de 600 , talvez seestivesse a pecarpor excesso. A Encyclopédie Larousse de la Nature indica "457 vítimas" (E. V. NOVA, 1996). Um número ligeiramente acima dos 500 parece-nos mais razoável para o que vimos depois de encerradas as contagens oficiais.
Igualmente conhecidos são os casos das chuvas intensas em climas tropicais, seja na sequência de ciclones, seja na sequência daquilo a que muitas vezes se chama a "chegada da monção". No nosso país, são geralmente objecto de grandes reportagens mediáticas os ciclones tropicais das Caraíbas ("furacões"), em especial quando afectam cidades dos Estados Unidos, ou os do Sul da China ("tufões"), em especial quando inundam as áreas urbanas de Hong Kong ou de Macau.

Menos conhecidos do grande público são os casos ocorridos sob climas tropicais quando da passagem de frentes muito activas. Mesmo assim, uma vez por outra, os nossos jornais noticiam inundações em Luanda ou no Rio de Janeiro, pelo menos quando elas conduzem à tragédia por desencadearem processos geomorfológicos de características catastróficas nas vertentes (caso dos 250 mortos no Rio de Janeiro a 10 de Fevereiro de 1988).

Ainda menos nossos conhecidos são os casos de climas temperados de características continentais, marítimas ou de transição, onde, embora globalmente mais raras, as inundações rápidas em espaço urbano podem ser importantes. No entanto, e embora não possam chamar-se catastróficas, as inundações de verão acontecem em cidades até bem próximas de nós, como foi o caso de Madrid em 24 de Junho de 1995 (M. A. A. COCA e F. F. GARCIA, 1996).

Em todas estas situações há um ponto comum - a ocorrência de chuvas intensas, isto é, de muita precipitação em pouco tempo (Quadro II). E as chuvas intensas são nitidamente um risco climático, maior ou menor consoante o tipo de clima, risco que se relaciona com a frequência da passagem de importantes depressões ou perturbações frontais. No entanto, e porque quando se fala em clima não se podem negligenciar os factores climáticos, para o mesmo tipo de clima, o risco das chuvas intensas será maior se se verificarem algumas características fisiográficas regionais ou locais susceptíveis de acrescentarem efeitos de ascendência orográfica (Quadro III).

Quadro II - Alguns exemplos de recordes horários de precipitações

\begin{tabular}{llrrr}
\hline \multicolumn{1}{c}{ Dia } & \multicolumn{1}{c}{ Local } & Quantidade & Duração & Média horária \\
29.11 .1911 & Porto-Bello (Panamá) & $62 \mathrm{~mm}$ & $3 \mathrm{~m}$ & $(1200 \mathrm{~mm} / \mathrm{h})$ \\
29.11 .1911 & Oklahoma (E.U.A.) & $106 \mathrm{~mm}$ & $5 \mathrm{~m}$ & $(1200 \mathrm{~mm} / \mathrm{h})$ \\
27.02 .1939 & Ambre (Madagáscar) & $318 \mathrm{~mm}$ & $1 \mathrm{~h} 10 \mathrm{~m}$ & $260 \mathrm{~mm} / \mathrm{h}$ \\
20.03 .1868 & Moligt-Les-Bains (F) & $313 \mathrm{~mm}$ & $1 \mathrm{~h} 30 \mathrm{~m}$ & $209 \mathrm{~mm} / \mathrm{h}$ \\
21.10 .1892 & Marselha (F) & $210 \mathrm{~mm}$ & $3 \mathrm{~h} 50 \mathrm{~m}$ & $55 \mathrm{~mm} / \mathrm{h}$ \\
$? 08.1933$ & Orba (Sicilia, It.) & $554 \mathrm{~mm}$ & $8 \mathrm{~h}$ & $69 \mathrm{~mm} / \mathrm{h}$ \\
\hline
\end{tabular}

Fonte: Ch. PÉGUY(1970)

Quadro III - Alguns exemplos de máximos de precipitação em 24 horas sob clima mediterrâneo de altitude

\begin{tabular}{rlr}
\hline \multicolumn{1}{c}{ Dia } & \multicolumn{1}{c}{ Local } & Quantidade \\
$? .10 .1940$ & Haut Vallespir (F) & $>1000 \mathrm{~mm}$ \\
30.10 .1963 & Mont-Aigoual (F) & $608 \mathrm{~mm}$ \\
24.02 .1924 & Mont-Aigoual (F) & $520 \mathrm{~mm}$ \\
$?$ & Penhas Douradas (P) & $234,5 \mathrm{~mm}$ \\
\hline
\end{tabular}

Fontes: G. VIERS (1968), P. ESTIENNE et A. GODARD (1970) e Normais Climatológicas de Portugal, 1930-60. 


\section{Escoamento natural e escoamento artificial}

A existência de condições climáticas favoráveis à ocorrência de inundações rápidas não signnifica forçosamente que elas aconteçam. Se-as chuvas intensas ocorrerem numa região onde os rios e ribeiros apresentem características naturais que lhes permitam uma boa drenagem, não surgirão problemas - a região estará em equilíbrio com o seu clima.

Todavia, muitas vezes, as ribeiras e os rios, ou já se apresentam com caudais importantes e não aceitam muito mais água sem transbordarem, ou, estando quase secos, já se encontram numa fase de entulhamento, com leitos muito sobrecarregados de aluviões e não podem oferecer um canal com capacidade suficiente para o escoamento rápido de grandes volumes de água. Além disso, nem todos os materiais rochosos que lhes servem de base se comportam da mesma maneira no respeitante a infiltração e a retenção de água.

A estes problemas naturais ligam-se, com frequência, problemas humanos e o risco hidrológico ganha uma outra dimensão.

Salvo algumas e até notáveis excepções, o homem sempre procurou a proximidade dos rios para se instalar; com o tempo, ganhando uma consciência empírica do risco, foi-se habituando a fugir das áreas de maior probabilidade de cheia, ou a conviver com ela através de habitações palafíticas ou de habitações jangadas, especialmente quando se tratava de grandes rios e de inundações habituais e frequentes. O exemplo do Amazonas é um dos mais conhecidos - seja em área urbana, como em Manaus, na margem esquerda do rio Negro ou mesmo nos chamados igarapés no interior da cidade, onde predominam as casas palafíticas, seja nas ilhas inundáveis em pleno rio, onde se podem ver muitas habitações-jangadas mais ou menos presas a árvores de grande porte. No caso de áreas susceptíveis de inundações rápidas, em muitas cidades, só a pressão demográfica levou a que certos locais de risco fossem sendo progressivamente ocupados, às vezes por pessoas vindas de fora, sem o tal conhecimento empírico, outras vezes por pessoas confiantes nas obras de engenharia ditas capazes de responder à ocorrência das situações mais graves.

No respeitante a estes últimos casos, coloca-se sempre o problema do escoamento das águas pluviais, que, nas cidades, se vem tornando cada vez mais artificial.

Ao abrir uma nova rua ou avenida revela-se necessário muitas vezes modificar o escoamento natural da área da sua implantação (F. REBELO, 1994, p. 12). Poderá fazer-se uma simples canalização a céu aberto, ao lado, como poderá mesmo ter de se fazer um grande canal com traçado mais ou menos próximo do que era o traçado natural do rio ou ribeira existente, construindo diques laterais, em terra, pedra ou até cimento. Na maior parte das vezes, porém, optar-se-á por uma canalização subterrânea.

Será, então, fundamental conhecer com exactidão os caudais máximos atingidos no curso de água a trabalhar; os modelos matemáticos ajudam muito, mas pareceria bem mais importante equacionar as quantidades máximas de chuva por unidade de tempo com o volume do canal a abrir ou com o diâmetro das manilhas a utilizar no escoamento das águas pluviais. $E$ aqui surge o problema de não ser fácil conhecer aquela variável uma vez que há poucas estações meteorológicas com instrumentos de registo da intensidade das precipitações e, quando existem, os dados conhecidos são poucos e recentes. Além disso, em iguais condições de tempo, não chove o mesmo em todas as áreas da cidade e, por maioria de razão, nas áreas periféricas. Muitas vezes, é das áreas periféricas, dos arredores das cidades, que surgem verdadeiras enxurradas perfeitamente imprevistas.

A tudo isto, acresce que as canalizações subterrâneas são, evidentemente, impermeáveis e as canalizações a céu aberto nem sempre correspondem à simples construção de diques laterais mantendo um leito natural - há casos de canais urbanos totalmente em cimento. E há, principalmente, a impermeabilização dos espaços de circulação, em regra com asfalto, e de grande parte dos espaços construidos, quase sempre com cimento. Todas estas impermeabilizações, a que frequentemente se acrescenta o total ou parcial entulhamento das sarjetas com folhas ou pedras arrastadas pela água da chuva, vêm agravar uma eventual inundação rápida provocada pela falta de resposta dos meios artificiais de escoamento, particularmente se se trata de uma canalização subterrânea. A velocidade de propagação da "cheia" na cidade é, portanto, aumentada pelo facto de haver poucas perdas por infiltração.

De qualquer das formas, para resolver o problema do escoamento urbano é preciso jogar sempre com os valores máximos previsíveis das chuvas intensas.

A topografia urbana poderá levar a situações crónicas de alagamento. A existência de muros ou de outras barreiras no percurso das águas começará por originar a sua subida no local e virá a criar problemas de maior gravidade no momento em que a sua oposição for vencida.

Muitas vezes, as inundações rápidas são agravadas por factores naturais como o transbordamento de rios ou a ocorrência de preia-mar muito elevada. Menos vezes, felizmente, o agravamento vem da viscosidade que as águas ganham em função de movimentos de terrenos (movimentos em massa), nas suas bacias hidrográficas, desde os que se originam em aterros ou desaterros relacionados com pequenas obras de construção civil até aos que ocorrem na 
sequênciada destruição do coberto vegetal por incêndios de mato ou de floresta, passando, claro está, por trabalhos de abertura de estradas ou por trabalhos de deflorestação com arranque de árvores. Tornando-se viscosa, a água de escorrência terá, logicamente maior energia; e se transportar troncos de árvores em suspensão ou em flutuação poderá apresentar-se com uma enorme força destruidora.

\section{Alguns casos de catástrofes em espaços urbanos portugueses}

Em Portugal, são relativamente frequentes as inundações rápidas. Casos de partes de cidades ou de vilas sofrendo durante algumas horas as consequências de chuvas muito intensas conhecem-se desde há muito tempo. Faro tem sido um exemplo muito referido na comunicação social; há perto de vinte anos, tivemos, mesmo a possibilidade de ver no local os efeitos da passagem lenta de uma depressão que, num dia de Dezembro, provocou chuvas intensas e, por isso, grandes inundações. Mas, bem longe de Faro, Águeda também tem sido atingida por inundações que, embora directamente relacionadas com o rio do mesmo nome, têm a ver igualmente com situações de ponta criadas pela ocorrência de chuvas intensas. Porto, Coimbra, Setúbal, têm sido, também, referenciadas. O caso mais mediático, todavia, será o de Lisboa que tem já sítios crónicos de inundação sempre que ocorrem chuvas mais fortes; por diversas vezes, pudemos observar alguns deles em plena situação de crise.

Na maioria das ocasiões só o trânsito é afectado. Com certa frequência, porém, a água entra em casas de habitação e em casas comerciais e há prejuizos, nem sempre cobertos pelos seguros. Têm sido raras, felizmente, as crises de grandes proporções ligadas a chuvas intensas originando catástrofes em espaços urbanos; no entanto, nos últimos 30 anos, algumas ficaram na história do nosso país - destaquemos as que ocorreram na região de Lisboa em 1967, no Funchal em 1993 e na Povoação em 1986.

\section{Região de Lisboa}

O caso mais dramático deste tipo de actuação das águas em meio urbano acontecido no território de Portugal continental foi, sem dúvida, o da região de Lisboa, de 25 para 26 de Novembro de 1967, que provocou mais de 500 mortos e muitos milhões de contos de prejuizos.

I. AMARAL (1968) publicou uma nota sobre essa crise em que mostrava claramente as suas piores consequências e analizava com grande minúcia as suas causas. Poucas vezes Portugal teria assistido a resultados tão funestos da conjugação de fenómenos meteorológicos originadores de chuvas intensas (depressão muito cavada e sistema frontal), com uma grande abundância de água nos solos após época bastante chuvosa e com uma forte vulnerabilidade humana devida à pressão demográfica e a alguns erros urbanísticos.

Quanto às características meteorológicas, salientou-se, então, "um sistema depressionário formado na região do arquipélago da Madeira e que, desde 24 de Novembro, se começou a deslocar para nordeste, em direcção a Lisboa; aos efeitos desta depressão juntaramse os de um sistema frontal que precedia uma massa de ar polar, de trajecto marítimo, transportada na circulação de um anticiclone centrado a norte dos Açores, deslocando-se com vento forte ou muito forte" (I. AMARAL, 1968, p. 79). Mais tarde, D. B. FERREIRA (1985, p. 32-36) veio a considerar "a situação de 23 a 26 de Novembro de 1967" como "um exemplo particularmente demonstrativo da actividade pluviométrica" das "interacções das circulações polar e tropical" explicando-a em pormenor e integrando-a no conjunto das "depressões convectivas da bacia atlântica norte subtropical oriental", num tipo que pode ocorrer "no outono e princípio do inverno".

No respeitante aos problemas de ordem humana que ajudaram à gravidade das consequências, I. AMARAL apontou, em primeiro lugar, a falta de preparação "dos esgotos das áreas urbanizadas"; mas falou também das "vertentes desnudadas de vegetação, cobertas de solos abandonados pela lavoura e onde nos últimos anos se têm multiplicado as superfícies impermeabilizadas" (p.81). A sua análise da crise recaíu especialmente na bacia hidrográfica do rio Trancão, da qual apresentou uma figura, onde se destaca uma certa circularidade favorável a respostas rápidas às chuvas intensas (fig. 1), e cinco fotografias muito bem escolhidas como representativas da destruição verificada.

Trata-se de um rio com cerca de $40 \mathrm{Km}$ de extensão, que organiza a drenagem de um conjunto de ribeiras com as características de linhas de água de uma bacia de recepção que, nas suas partes mais altas, pouco ultrapassa os 400 metros de altitude. Já na sua secção terminal, recebe, através da ribeira de Loures, a drenagem de três ribeiras (a de Loures, a de Fanhões e a dos Pombais), apresentando-se, a partir daí e até à planície aluvial do Tejo, antes de nele desaguar, com um canal de escoamento de fraquíssimo declive longitudinal, mas bem definido transversalmente por um encaixe de mais de 100 metros.

Com uma planície aluvial, que envolve também as áreas finais daquelas três ribeiras, funcionando, praticamente, como uma digitação da do Tejo, o Trancão inundou-a também por ter ficado impedido 


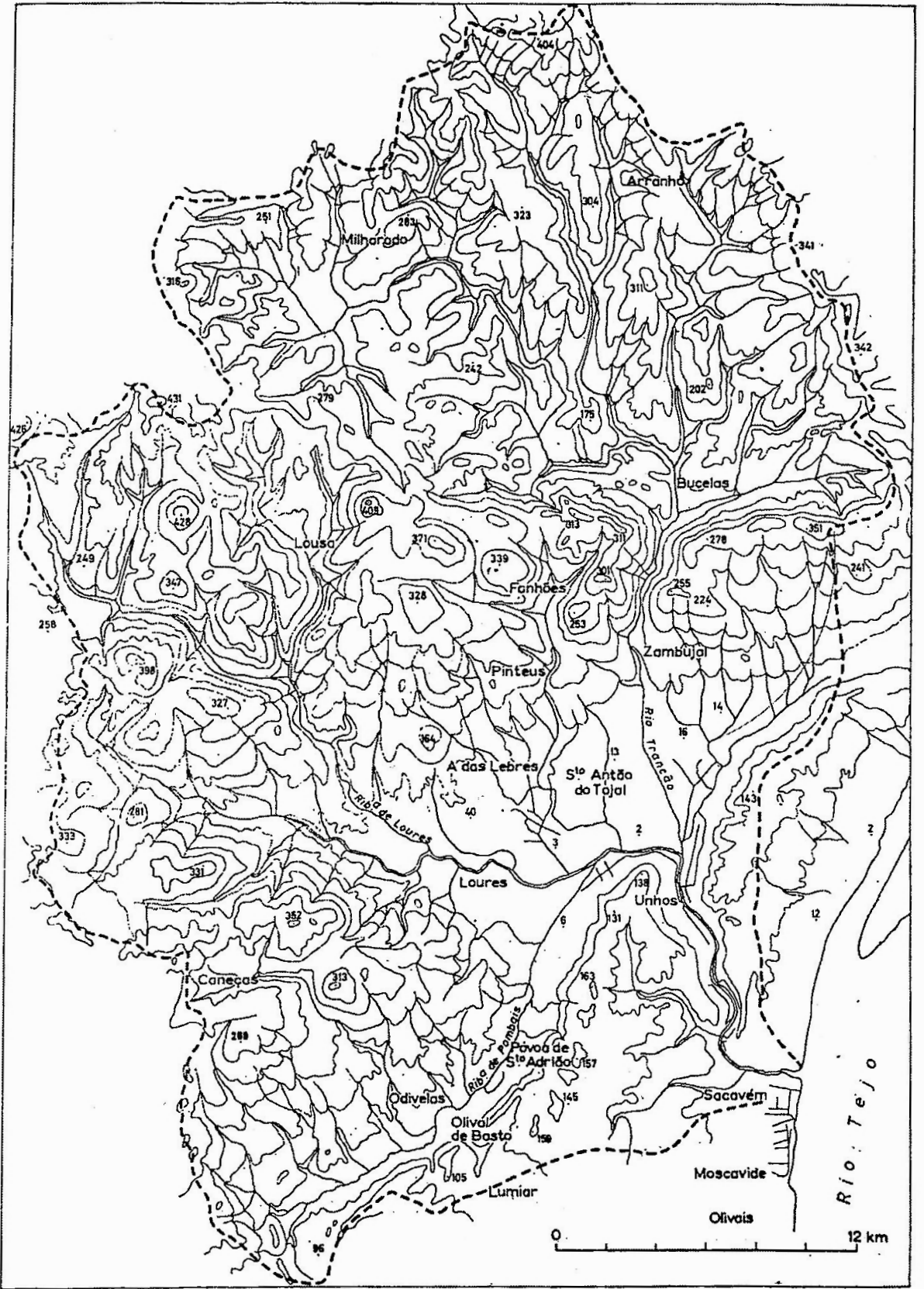

Fig. 1 - Bacia hidrográfica do Rio Trancão.

Figura extraída de I. AMARAL (1968). Equidistância das curvas de nível: 50 metros. de escoar as suas águas. Aliás, na parte terminal dos seus cursos, várias ribeiras tiveram cheias porque o Tejo não deu vazão imediata às suas águas.

Tal não foi o caso que, pessoalmente, vivemos nessa noite-o problema das inundações então ocorridas em Alapraia (S. João do Estoril), onde uma recente urbanização ocupava o fundo amplo de um vale seco instalado em terrenos calcários a cotas entre os $30 \mathrm{e}$ os 50 metros de altitude. No mapa topográfico vê-se que a linha de água em causa tem as suas cabeceiras à volta dos 90-110 metros e a uma distância de cerca de 2,5 Km do local (fig. 2). Na área, há grutas, algumas conhecidas desde há muito pelo seu espólio pré-histórico (E. JALHAY e A. PAÇO, 1941), mas não havia memória de uma inundação. Ou seja, o risco existia devido às características climáticas regionais (clima mediterrâneo com influências atlânticas) e às características topográficas (fundo de vale) e hidrogeológicas (circulação subterrânea em rochas calcárias) locais, mas ninguém tinha consciência dele, por não se recordar de qualquer situação de crise que tivesse acontecido. 


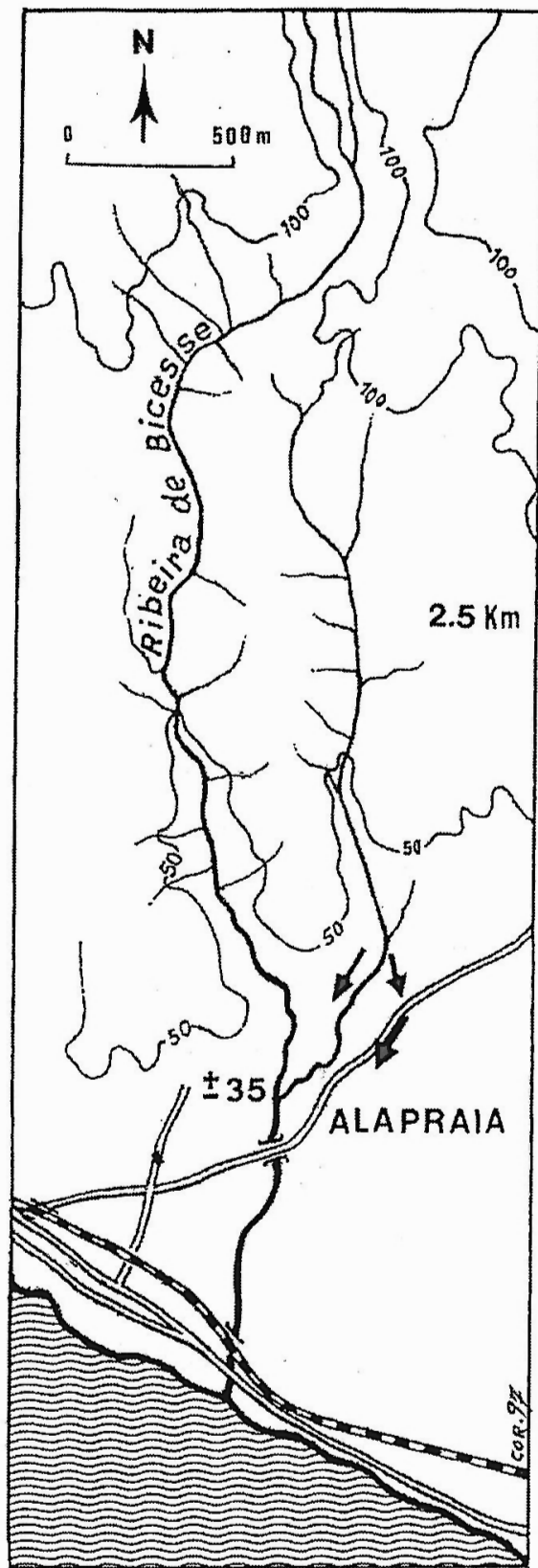

Fig. 2 - Esboço de localização da área da Alapraia (1967). As setas indicam a direcção das águas em fúria.

O máximo da precipitação terá sido entre as $20 \mathrm{e}$ as 21 horas do dia 25 ; como aquele Outono tinha sido muito chuvoso, pensando na já referida (Quadro I) sequênciade conceitos da "teoriadorisco"(L.FAUGÈRES, 1990), o perigo era eminente. A água que, por volta das 20.30, já escorria pela velha Estrada da Alapraia era, indubitavelmente, um sinal, mas também não foi tida como tal por ninguém. A verdade, todavia, é que a resposta das linhas de água ainda não urbanizadas foi rápida, a rede de drenagem artificial não foi suficiente para o escoamento e a crise desencadeou- -se. A estrada depressa se transformou em rio caudaloso. Às 23 horas já as águas passavam brutalmente, com um ruido enorme e contínuo, inundando as casas térreas e o rés-do-chão de muitos edifícios; uma rua paralela, nova, também situada no mesmo fundo de vale, foi enchendo até cerca de um metro e meio de altura, exactamente a altura do muro transversal que a tornava um beco sem saída - quando o muro cedeu, a velocidade das águas aumentou bruscamente e a rua transformou-se numa torrente caudalosa que avançava sobre alguns quintais e se lançava numa outra rua, para mais além confluir na Estrada da Alapraia. A essa hora já muitas pessoas das casas térreas tinham subido para o telhado e, debaixo da chuva forte que continuava a cair, agarradas às chaminés, gritavam por um socorro que não podia chegar.

Muito perto, a estação do Monte Estoril tinha registado, entre as $20 \mathrm{e}$ as 21 horas, $60 \mathrm{~mm} \mathrm{de}$ precipitação, mais de um terço da que registou em 24 horas (das 10 de 25 às 10 de 26) - $158,7 \mathrm{~mm}$. Tratou-se, sem dúvida, de um valor "record" para a região. "Casos de precipitação superior a $20 \mathrm{~mm}$ numa hora já se tinham registado em muitos outros anos; por exemplo, em Setembro de 1918, as ocorrências de $51 \mathrm{~mm}$ numa hora e $70 \mathrm{~mm}$ em duas horas, em Lisboa, ficaram como acontecimentos excepcionais" (I. AMARAL, 1968, p. 79-81).

Na medida em que as condições naturais são as mesmas e as vulnerabilidades existem, o risco de inundação rápida na região de Lisboa não está de modo algum ultrapassado. Todavia, essas vulnerabilidades não seriam já tão grandes em certas áreas quando uma situação de crise muito semelhante à de 25-26 de Novembro de 1967, igualmente em função de inundações rápidas provocadas por chuvas de grande intensidade, ocorreu, de novo, em 19 de Novembro de 1983; na realidade, e felizmente, não foi tão catastrófica e, em comparação, o número de mortos foi diminuto - apenas 7 (D. B. FERREIRA, 1985, p. 25). Ainda assim, perderam-se 610 casas (J. S. ROCHA, 1995, p. 17).

\section{Funchal, ilha da Madeira}

No que se reporta à ilha da Madeira, já "há notícia de 'temporais, tormentas e dilúvios' nos anos de $1724,1757,1759,1765,1774$ ", como nunca se apagou da memória colectiva "a catastrófica 'aluvião' de 1803. Na sequência deste 'dilúvio' de 1803, o extremo espinhaço da lombada entre as ribeiras da Caixa e da Ponta do Sol desmoronou-se pela encosta abaixo, formando a fajã onde hoje fica o Lugar de Baixo" (J. M. A. SILVA, 1995, p. 56). Na verdade, a origem deste tipo de catástrofes está, antes de tudo, 
na chuva muito intensa, pelo que se compreende a utilização da palavra "dilúvio" e tem por consequências, em regra, piores para a população, as grandes inundações em espaço urbano que deixam mantos de lama, areia, calhaus e lixo assim justificando bem a utilização da palavra "aluvião" que, na Madeira, ganhou um significado muito mais amplo do que no vocabulário científico.

Segundo o "Elucidário Madeirense", referido por R. QUINTAL e M. J. VIEIRA (1985, p. 30), também no século XIX se verificaram diversas "aluviões" - para além da de 1803 , as de 1815,1842 , $1848,1856,1876$ e 1895 - e, no século $X X$, as de 1901,1920 e 1921 . Os mesmos autores salientaram, então, que as "situações atmosféricas responsáveis por grandes destruições se verificaram entre Outubro e Março, não tendo havido (...) qualquer caso verdadeiramente significativo no mês de Dezembro". Salientaram, igualmente, que, "de todos estes, o mais violento foi o temporal que ocorreu em 9 de Outubro de 1803". E extraíram do "Elucidário Madeirense" um texto que consideraram interessante - "Tinham caído algumas chuvas, com várias intermitências, nos 10 ou 12 dias que precederam o 9 de Outubro de 1803. Neste dia, pelas 8 horas da manhã, começou a cair no Funchal uma chuva muito copiosa, que se manteve inalteravelmente até às 8 horas da noite, mas nada fazia recear que estivesse eminente uma tão terrível inundação. Principiou então a ouvir-se o ribombar do trovão e a chuva, acompanhada de algum vento, caía já em verdadeiras catadupas. Às oito horas e meia as águas das ribeiras galgaram as suas margens e espalhavam-se com grande ruído pelas ruas laterais, começando a sua obra de destruição e morte. Estava-se em pleno dilúvio" (R. QUINTAL e M. J. VIEIRA, 1985, p. 30).
Outros temporais se abateram sobre a ilha da Madeira em tempos mais recentes. Ficaram tristemente célebres, por exemplo, o de 3-4 de Novembro de 1956, que causou a morte a 30 pessoas, e o de 23-24 de Janeiro de 1979, que originou 12 mortes (D. B. FERREIRA, 1985, p.25). R. QUINTAL e M. J. VIEIRA (1985) estudaram as situações sinópticas de um e de outro e descreveram largamente as suas consequências um pouco por toda a ilha.

No entanto, no que respeita à cidade do Funchal, foi preciso esperar por 29 de Outubro de 1993 para se ficar com uma ideia do que terá sido a tragédia de 1803 . Entre as $0 \mathrm{e}$ as 6 horas desse dia foram registados $231 \mathrm{~mm}$ no posto do Poiso, situado a 750 metros de altitude, nas proximidades do Funchal. A ribeira de João Gomes vem dessa área passando ao lado do Terreiro da Luta em direcção ao centro da cidade; aqui, encontra-se canalizada, digamos, apertada entre ruas, desaguando depois de passar por baixo da Avenida do Mar, quase ao lado de uma outra ribeira, a de Santa Luzia. Esta, que the fica a ocidente, é mais extensa, nasce a maior altitude (muito perto do Pico do Areeiro, terceiro ponto mais alto da ilha $-1818 \mathrm{~m}$ - depois do Pico Ruivo - 1862 - e do Pico das Torres - 1851 - cfr. R. QUINTAL, 1994, p. 14), tem uma bacia hidrográfica maior e, em grande parte do seu traçado urbano, também corre apertada entre ruas - no caso, as ruas 31 de Janeiro e 5 de Outubro (fot. 1). Uma outra ribeira do centro da cidade merece referência especial - a de S. João, que, na sua secção terminal, corre apertada entre a Rua Dr. João Brito Câmara e a rua onde se encontra o Quartel dos Bombeiros, o Auto-silo e os CTT desaguando em túnel em pleno porto, ao lado da Marina; esta ribeira resulta da junção de várias ribeiras, todas de forte declive longitudinal, uma das quais nasce igualmente na área do Pico do Areeiro (fig. 3).

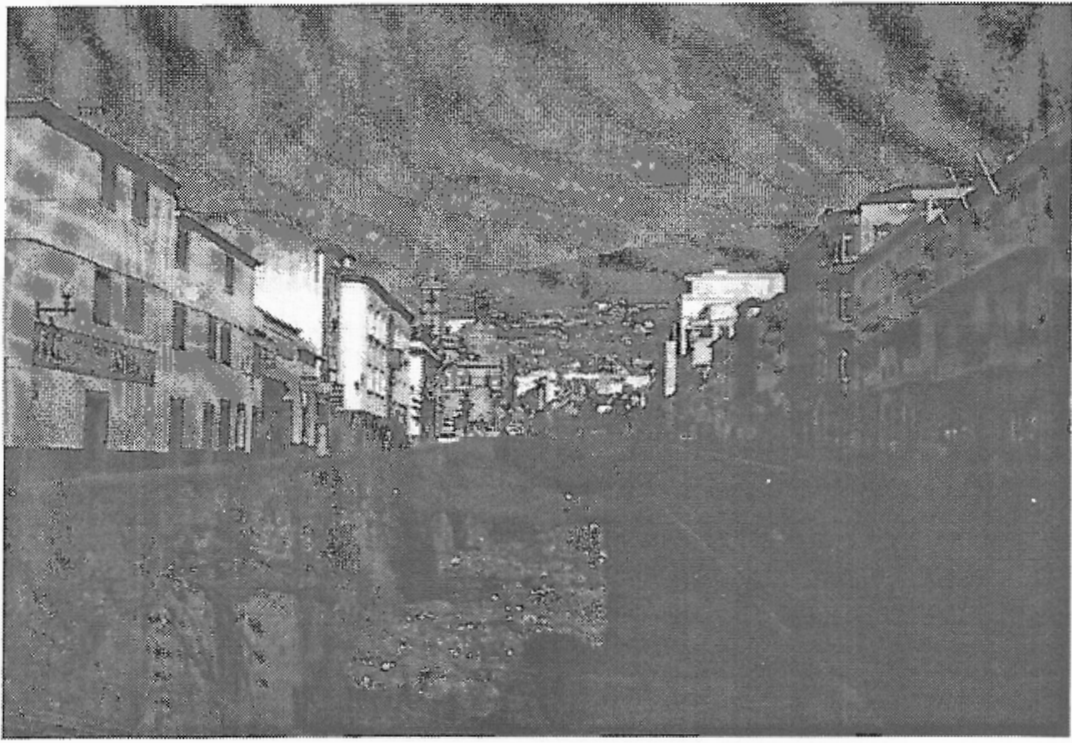




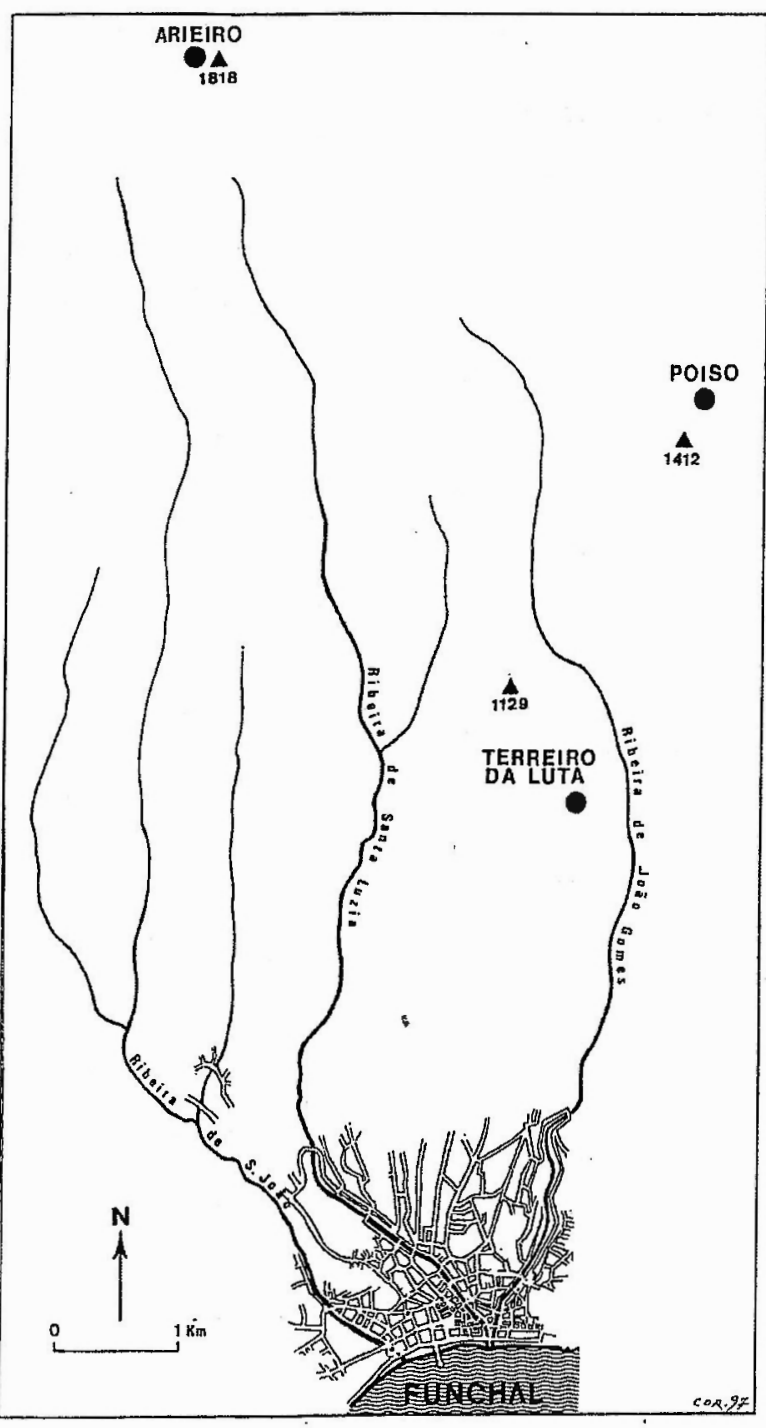

Fig. 3 - Ribeiras do Funchal. Esboço de localização salientando exclusivamente o centro da cidade e as principais altitudes dos arredores.

Naturalmente, naquele dia, cada uma destas ribeiras se tornou, mais doque um rio caudaloso, uma verdadeira torrente lamacenta com um potencial erosivo enorme e ao longo do seu percurso destruiu diques, muros e estradas, casas e automóveis, depositando aqui e ali materiais de grandes dimensões; no entanto, no centro da cidade, como que retomando aquilo que, antes da construção das casas, havia sido o seu cone de dejecção, provavelmente comum, as ribeiras de João Gomes e de Santa Luzia transbordaram e cobriram de água, lama e lixos variados as ruas, praças, quintais e parques de estacionamento da baixa da cidade (M. F. FERREIRA, 1995). Muitas casas se viram invadidas pelas águas e os prejuizos foram elevadíssimos. Felizmente, e ao contrário das inundações de 1803, que terão matado umas 600 pessoas, estas inundações de 1993 poucas mortes causaram - dois dias depois o Diário de Notícias (Lisboa, 31 de Outubro de 1993) falava em 5 mortos, 2 desaparecidos e 180 desalojados, juntando o caso do Funchal ao da Câmara de Lobos, onde também se verificaram inundações e temporal no mar.

A análise do risco de inundação na baixa da cidade do Funchal leva-nos, salvo no que diz respeito à importância da orografia, a considerações de ordem climática semelhantes às que se fizeram para a região de Lisboa - a possibilidade de ocorrrerem depressões muito cavadas, associadas ou não à passagem de sistemas frontais com frentes frias particularmente activas. As depressões, cuja maioria se forma na área, podem ficar quase estacionárias durante alguns dias sobre a ilha e, embora de pequena dimensão, comportam-se como verdadeiras bombas geradoras de chuvas. Ao estudá-las, D. B. FERREIRA (1985) falou da "brutalidade das quedas de chuva" que ocasionam, da "indecisão da trajectória seguida pelos sistemas nebulosos" e "na sua intensificação inesperada" (p. 26), considerou "vários tipos de sistemas convectivos evoluindo na zona subtropical do Atlântico oriental" e sublinhou como importante para a sua actividade "a combinação favorável de vários factores, dinâmicos e geográficos, de escalas diferentes". Entre esses factores, salientou, por exemplo, "a presença de ar quente e húmido nas baixas camadas (ar marinho local ou advecção de ar tropical marítimo instável)", tal como a importância das montanhas, quando terminava dizendo que "os arquipélagos montanhosos jogam um papel local importante para fixar as núvens cumuliformes e aumentar as quedas pluviométricas" (p. 41-43).

As características hidrográficas das ribeiras não se poderão comparar com as do Rio Trancão, e muito menos com as do referido caso concreto da Alapraia (S. João do Estoril), na região de Lisboa; as ribeiras madeirenses drenam áreas de muito maiores altitudes, têm extensões próximas dos $10 \mathrm{Km}$ e apresentam bacias mais rectangulares do que circulares - os fortes declives longitudinais em longos tramos, quase rectilíneos, na maior parte dos seus percursos, apesar da inexistência de circularidade nas bacias, parecem ser francamente mais favoráveis à ocorrência de inundações rápidas. No entanto, a pressão demográfica urbana, que levou ao apertar dos canais de escoamento, quando a natureza teria originado o seu alargamento e a sua divisão em múltiplos pequenos canais nos cones de dejecção, tal como a pressão demográfica peri-urbana ou rural, que levou ao desaparecimento de partes importantes do coberto vegetal, fosse por incêndios florestais ou de mato, fosse por arroteamentos ou por sobrepasturagem, são factores que têm muito de comum com o que se passou nos arredores de Lisboa. 


\section{Povoação, ilha de S. Miguel, Açores}

Em 2 de Setembro de 1986, ocorreu na vila da Povoação uma catástrofe do género das anteriormente expostas (F. REBELO e A. G. B. RAPOSO, 1988). A constatação de apenas duas mortes foi então considerada um autêntico milagre atendendo à violência e à dimensão da crise.

O risco climático de ocorrência de chuvas intensas existe nos Açores com características semelhantes às da Madeira. Independentemente de outras causas, também no arquipélago dos Açores podem estacionar durante alguns dias "sistemas convectivos" que, de repente, descarregam chuvas diluvianas, segundo mecanismos diversos (D. B. FERREIRA, 1985). Embora as altitudes não sejam comparáveis às da Madeira, a oceanicidade e a presença próxima da corrente do Golfo poderăo ser factores importantes a considerar para compreender os valores de precipitação registados, por vezes, nas ilhas açoreanas. D. B. FERREIRA (1985, p. 25), ao falar das chuvas de grande intensidade nos Açores, dá o exemplo do Faial, onde, "de 5 a 8 de Novembro de 1969, cairam mais de $620 \mathrm{~mm}$ de chuva no cimo da caldeira" e, no respeitante a consequências desse tipo de chuvas, refere um caso catastrófico - 68 mortos no dia 3 de Setembro de 1976.

O perigo de desencadeamento de uma catástrofe em S. Miguel estava eminente no início de Setembro de 1986, uma vez que os solos se encontravam muito mais encharcados do que habitualmente nessa época do ano e às 18 horas do dia 31 de Agosto já uma depressão tendia para estacionar sobre o arquipélago. No posto meteorológico de Ponta Delgada tinham-se registado $172,7 \mathrm{~mm}$ durante o mês de Agosto, valor excessivo, muito superior ao normal $(28,8 \mathrm{~mm}$, no período 1930-1960). De 31 de Agosto a 2 de Setembro, "no Planalto dos Graminhais, que funciona como 'fonte emissora' para as ribeiras da parte oriental da ilha, a precipitação terá ultrapassado os $350 \mathrm{~mm}$ " (F. REBELO e A. G. B. RAPOSO, 1988, p. 170).

A crise verificou-se na Povoação e no Faial da Terra não só pela manifestação do risco climático, mas pela sua conjugação com o risco hidrológico a que se acrescentavam alguns riscos geomorfológicos, mais ou menos agravados pela presença do homem.

Por se tratar da inundação de uma aglomeração urbana, ficou mais conhecido o caso da Povoação (fot. 2); no entanto, será importante referir que no Faial da Terra, onde estava em causa o funcionamento de uma só torrente (fot. 3), a catástrofe foi brutal. No caso da Povoação tratava-se do funcionamento de três torrentes (ribeiras de Lagos, do Purgar e da Lomba Grande) que convergem para um único canal de escoamento a montante da vila, onde depois se juntam ainda as pequenas ribeiras do Poiso dos Pombos e do Pé do Salto. Aqui, a situação hidrogeomorfológica seria já, francamente, de cone de dejecção se não tivesse havido a intervenção do homem desde há muito tempo; na verdade, canal de escoamento e cone de dejecção foram trabalhados e a secção terminal da rede aparece como um canal artificial, com diques laterais e pequenos "degraus" transversais de eficácia discutível. No conjunto da bacia hidrográfica das cinco torrentes da Povoação (fig. 4) há uma aproximação muito grande à forma circular (ou não drenassem uma caldeira de abatimento praticamente com essa forma) e no respeitante a declives verifica-se que, em 6 a $7 \mathrm{Km}$ de percurso, duas delas descem de perto de 1000 metros (área do Planalto dos Graminhais).

O desaparecimento da cobertura vegetal em partes significativas das bacias de recepção das torrentes favoreceu movimentações em massa nas vertentes



Fot. 2 - Povoação - canal de escoamento torrencial melhorado com obras de engenharia (1979). 
Fot. 3 - Faial da Terra (1979).

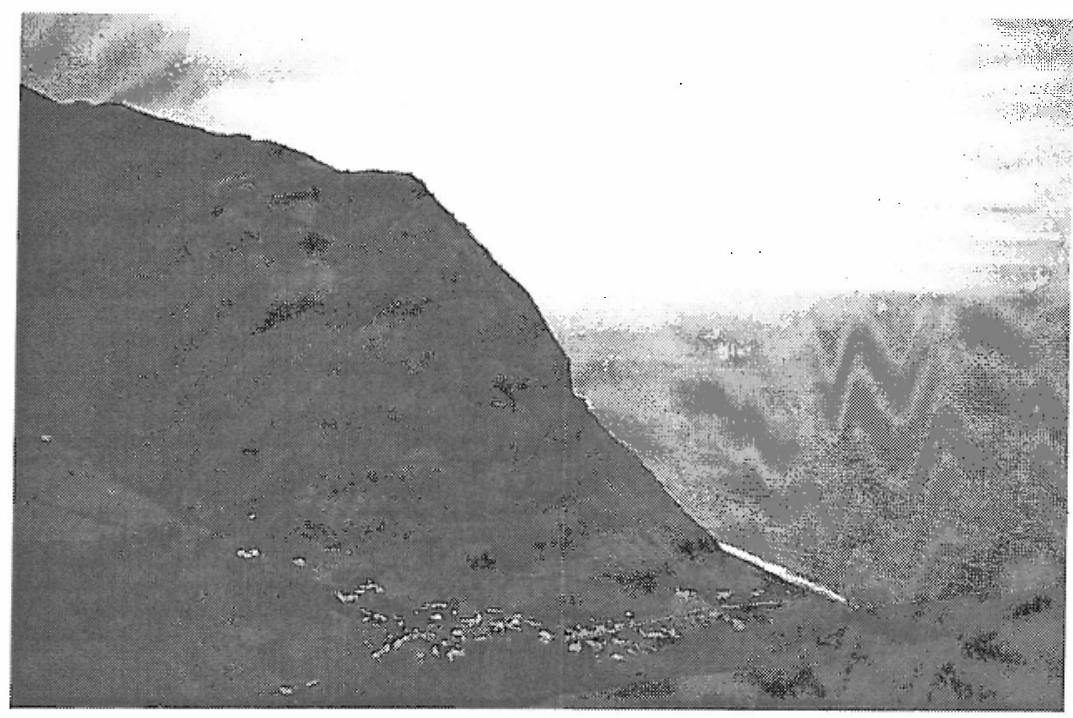

que vieram fornecer de lama e calhaus a água de escorrência e assim dar uma energia acrescida aos caudais de cheia. Árvores caídas por processos naturais ou cortadas pelo homem vieram igualmente enriquecer a força destrutiva das torrentes. As oito pequenas represas de correcção torrencial então existentes nas três principais ribeiras nada podiam fazer contra tal corrente lamacenta, que levava muros e pontes à sua frente; a vila viu-se rapidamente invadida - primeiro as ruas, depois as casas, tudo foi envolvido numa onda de destruição, como mostram as 5 fotografias que então publicámos (F. REBELO e A. G. B. RAPOSO, 1988, p. 176-178).

Dez anos depois, em finais de 1996 (sábado, 14 de Dezembro), a catástrofe repetiu-se; foi de dia, alguém filmou e a televisão, nos dias seguintes, mostrou repetidamente - impressionante é o mínimo que, quem viu, poderá dizer. Na segunda-feira seguinte,

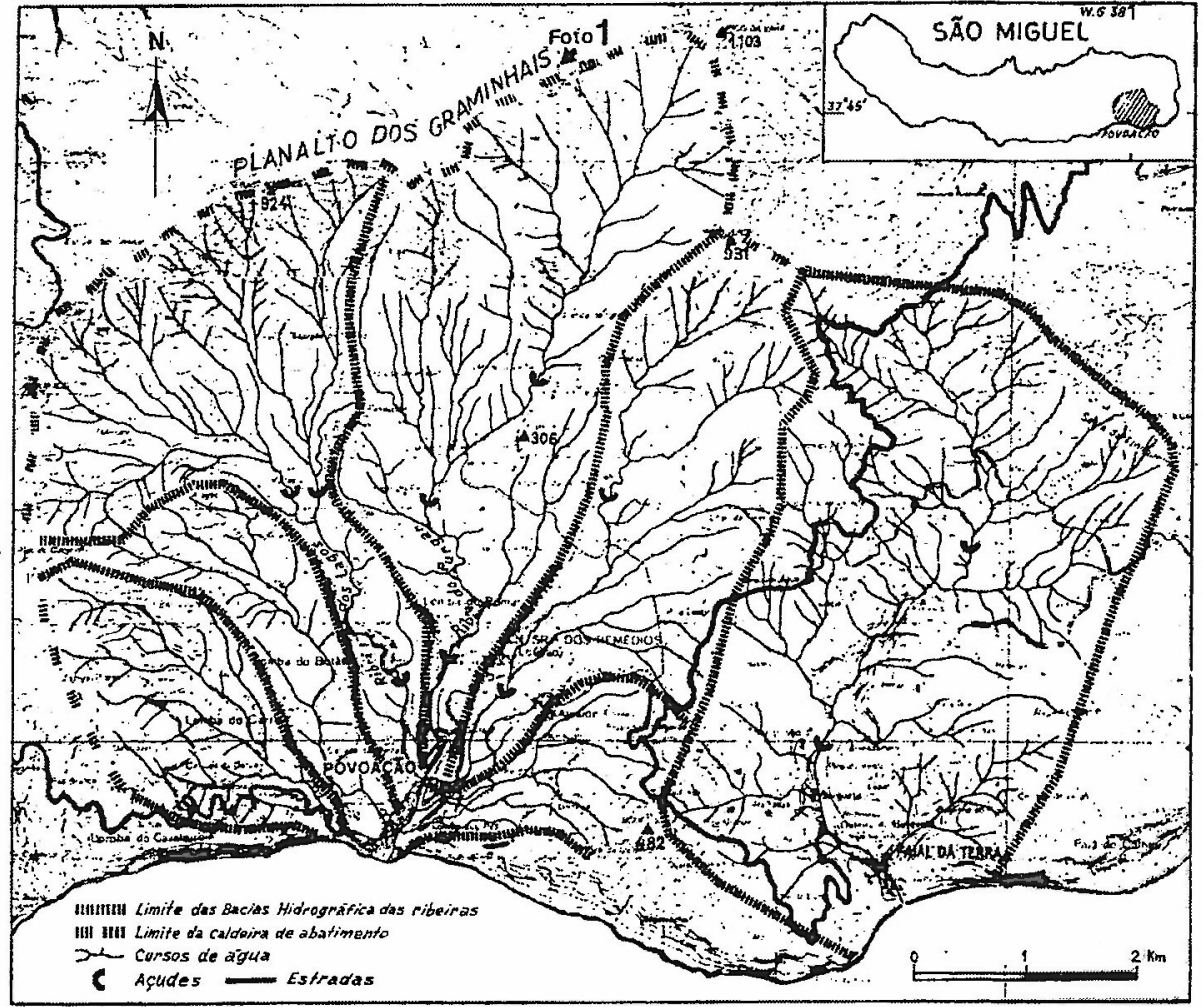

Fig. 4 - Bacias hidrográficas das ribeiras que convergem na Povoação e no Faial da Terra. Figura extraída de F. REBELO e A. G. B. RAPOSO, 1988. 
o Diário de Notícias (Lisboa, 16 de Dezembro), não se referia a mortos, mas falava na destruição de 200 moradias, 40 viaturas e algumas pontes ${ }^{(2)}$.

\section{Inundações rápidas à escala local - três casos típicos em Coimbra}

Durante séculos, e até aos inícios dos anos 80, Coimbra sofreu com as mais ou menos demoradas inundações das ruas da "baixa" provocadas pelo Mondego (A. F. MARTINS, 1940; F. REBELO, 1995b), que se podiam verificar nos meses de Inverno ou Primavera, mas que geralmente ocorriam entre Dezembro e Março. Além disso, Coimbra sofreu sempre também com inundações rápidas que aconteciam e ainda acontecem em determinados pontos da cidade, alguns correspondendo às mesmas ruas da "baixa". Previsíveis quanto aos locais, inesperadas quanto ao momento de ocorrência, elas verificavamse (e continuarão a verificar-se) quando se registavam (ou registarem) chuvas muito intensas. Naturalmente, nas ruas da "baixa" eram mais frequentes em épocas de águas altas do Mondego.

Estas crises, embora de limitadas proporções, trazem prejuizos a particulares e dão trabalho e despesas aos serviços municipais; também elas são manifestações do risco climático de chuvas intensas, aqui muito mais ligado à passagem de frentes frias, por vezes, quando se verificam ao meio da tarde, provavelmente relacionadas com efeitos térmicos localizados; e do mesmo modo, embora a outra escala tempoespacial, o risco climático interpenetra-se com o risco hidrológico, neste caso muitocomplexo na medida em que se verifica uma grande intervenção humana, por vezes, desde há centenas de anos.

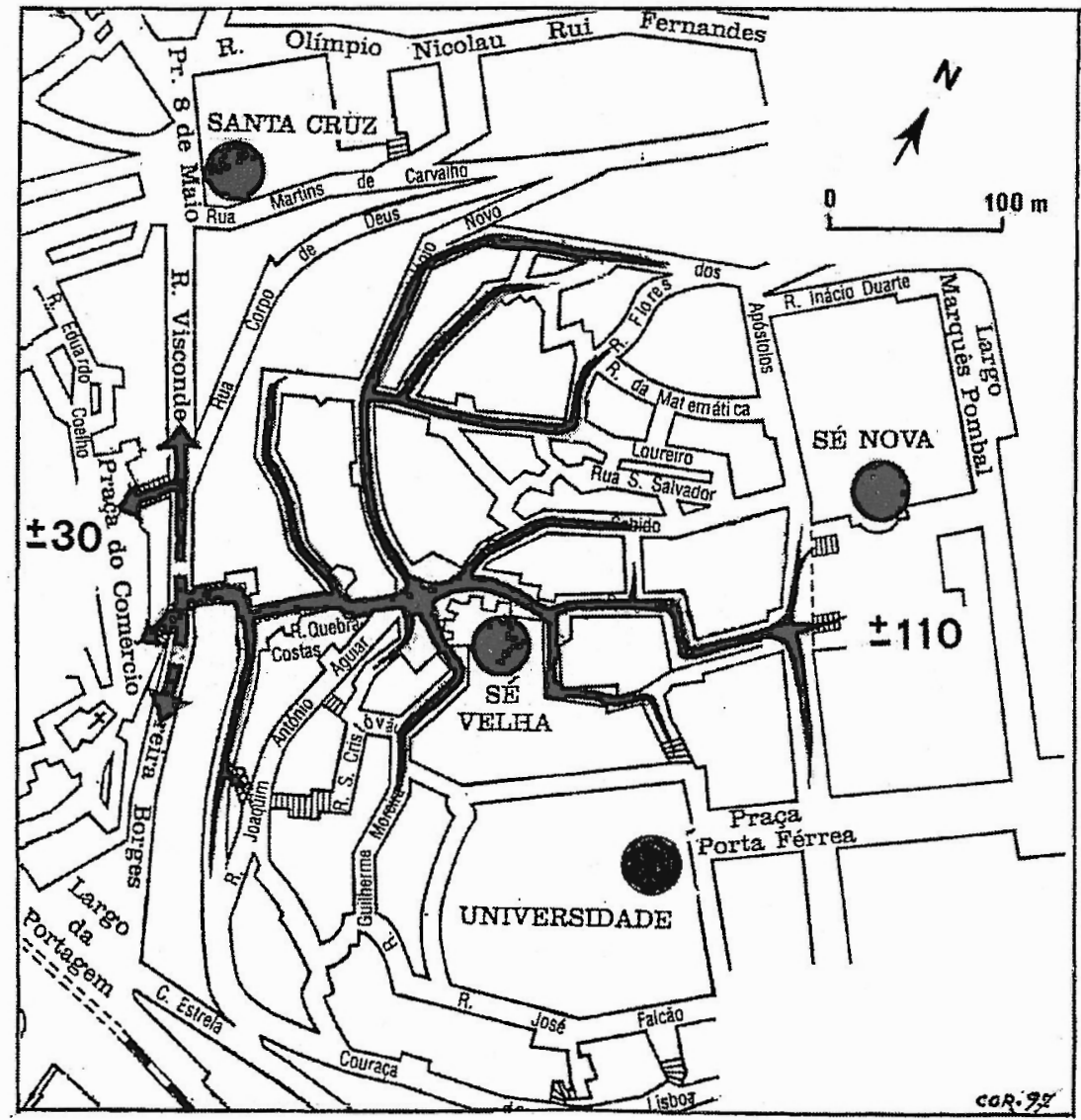

Fig. 5 - Coimbra - Bacia hidrográfica da pequena torrente da Sé Velha. Os traços a negro mostram os percursos da água descendo em direç̧ão à "Baixa". igualmente sobre a parte terminal de um canal de escoamento e sobre o cone de dejecção que o prolonga, originou uma catástrofe de grandes proporções por ter atingido um Parque de Campismo praticamente cheio. Foi em Biescas (Espanha), nos Pirinéus, na sequência de uma tempestade muito localizada em que se terão registado $152 \mathrm{~mm}$ de chuva em apenas uma hora; o número de mortos andou por volta dos 70 .

\section{A pequenissima torrente da Sé Velha}

Quando chove muito em pouco tempo, na chamada "Alta" de Coimbra (A. F. MARTINS, 1951, reed. 1983; A. P. MARGARIDO, 1987 e 1988) as ruas transformam-se em pequenos ribeiros torrenciais e as escadarias em cachoeiras. Com efeito, na área da Universidade, a água rapidamente ultrapassa a capacidade de drenagem da rede de esgotos ou pura e simplesmente a ignora, seja devido ao entulhamento com lixo e pedras, seja devido à maior ou menor velocidade em função do maior ou menor declive das ruas.

Tudo funciona como numa pequeníssima torrente com grande circularidade (aproximadamente $600 \mathrm{~m}$ por $500 \mathrm{~m}$ ), que, embora tenha as maiores altitudes da sua bacia de recepção apenas a cerca de 110 metros, apresenta, na sua maior extensão, um declive médio de cerca de $13 \%$ (fig. 5). Muito depressa a água se dirige para a "baixa", primeiro, convergindo 
na Sé Velha, onde, sob a forma de ruas, desde a Idade Média, se encontram algumas das antigas linhas de água da bacia. Desce, depois, bruscamente as Escadas do Quebra Costas, como se de um verdadeiro canal de escoamento se tratasse. Ainda recebe um canal afluente (Rua de Sub Ripas), a meio das Escadas, e um outro (Rua Fernandes Tomás), imediatamente antes da Porta da Barbacã. Aqui, a par com o aumento dos caudais, a estreiteza da passagem e o declive do canal de escoamento (fot. 4) são responsáveis por um último aumento da força viva das águas que logo a seguir divergem no início de cone de dejecção. No Largo entre as duas Portas poderão depositar-se materiais de maior dimensão. Passado o Arco de Almedina, a Rua Ferreira Borges (a uns 30 metros de altitude) é já a parte avançada desse cone - quase sem declive, ela provoca a deposição da maior parte do material transportado e a inundação das casas comerciais menos preparadas para enfrentar a crise.

Há alguns anos, numa tarde de chuva intensa, a agência bancária situada na esquina do Arco de Almedina com a Rua Ferreira Borges, além de inundada, ficou também cheia de areia, pedras e lixo diverso, bruscamente depositados pelas águas que a partir daí se dispersavam inundando casas comerciais e descendo pelas escadas de S. Bartolomeu para a Praça do Comércio (também chamada Praça Velha). Em casos extremos, uma parte dessas águas poderá seguir pela rua, tanto para norte como para sul; a que fôr para norte, juntando-se com a que desce pela Rua de Corpo de Deus poderá dividir-se num ramo que cai pelas escadas de $S$. Tiago e num outro que segue pela Rua Visconde da Luz até à Praça 8 de Maio, onde se encontra a Igreja de Santa Cruze onde será grandemente reforçada pela água que desce da Rua Martins de Carvalho.

\section{A pequena torrente de Santa Cruz - a antiga Ribela}

Em situações de chuva muito intensa, tal como já temos tido a oportunidade de verificar, há, sem dúvida, alguma água a seguir os referidos percursos para a Praça 8 de Maio. No caso da ocorrência de uma chuvada muito forte e com a ajuda de alguns elementos de origem humana, como o entupimento das sarjetas, a inundação poderáaí ser muito importante - é que, quase ao lado de Santa Cruz, termina a Rua Olímpio Nicolau Rui Fernandes, que também funciona como canal de escoamento, mas de uma torrente bem maior. Trata-se da antiga Ribela (A. F. MARTINS, 1951, reed. 1983, p. 61). A sua bacia de recepção é menos perfeita do que a da Sé Velha, em termos de circularidade, mas é mais extensa (cerca de $2 \mathrm{Km}$ de comprimento, para uma largura máxima de uns 750 metros); com altitudes próximas dos 150 metros no seu limite oriental, o declive médio desta torrente, desde a máxima altitude até Santa Cruz, ronda os $6 \%$ (fig. 6).

A principal linha de água desta bacia de recepção seguia pelo Parque de Santa Cruz (também chamado Parque da Sereia); cortada a montante por duas ruas e trabalhada no interior do Parque com estreitos caminhos e escadas, mesmo com chuvas intensas, pouco funcionará. Em sua substituição, uma rua (Rua Lourenço de Almeida Azevedo), rectilínea e com forte declive, canaliza o escoamento superficial para a Praça da República. Nesta Praça convergem mais quatro ruas, que completam o conjunto da bacia de recepção. Por quebrabrusca de declives e, consequentemente, da velocidade das águas, em situações de chuvas intensas, logo aí se podem depositar alguns materiais, como já por várias vezes pudemos observar.

Aágua, que, nesses momentos, desce muito depressa e em grande quantidade, em especial pela primeira dessas ruas, passa então a descer a Avenida Sá da Bandeira, avenida construida sobre um importante

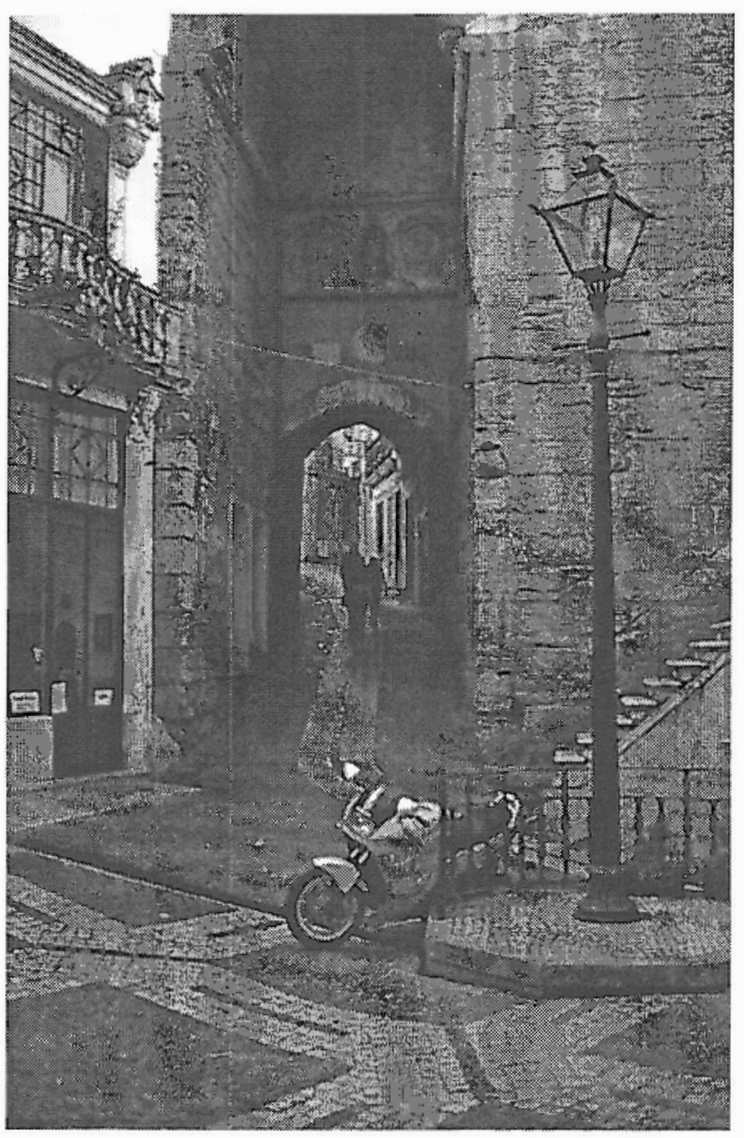

Fot. 4 - Coimbra - Porta da Barbacã (1996). 


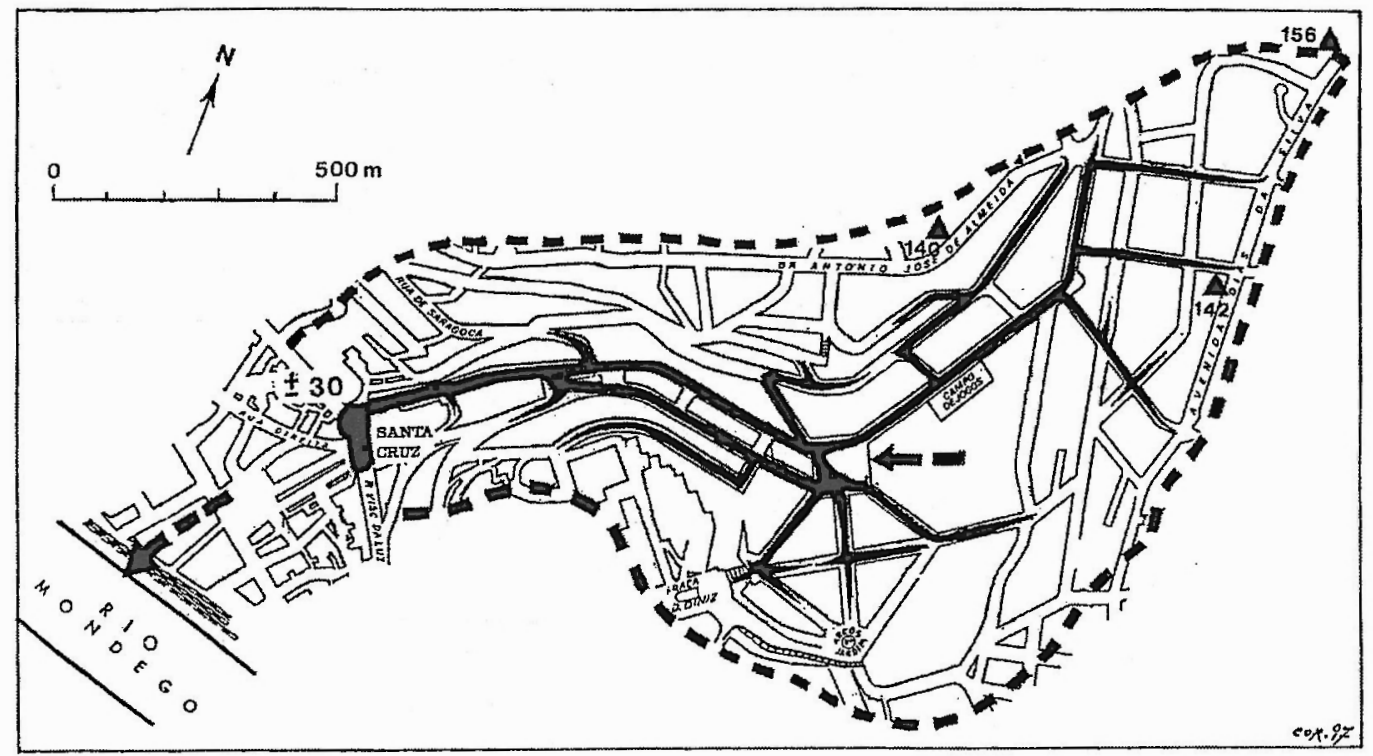

Fig. 6 - Coimbra - Bacia hidrográfica da Ribela. A negro representam-se os percursos da água descendo até ao largo fronteiro à Igreja de Santa Cruz (Praça 8 de Maio)

entulhamento que segue o traçado do canal de escoamento da referida torrente (fot. 5). Apesar da rede de esgotos e do grande colector hoje existente, a água continua a correr em grande quantidade à superfície. Mesmo que não cubra os passeios, a velocidade que atinge, durante (ou logo a seguir) ao episódio de chuvas muito intensas, particularmente na faixa descendente (lado norte), chega a impedir que qualquer peão tenha a veleidade de a atravessar. Ao fundo da Avenida, alguma água vinda pela faixa ascendente (lado sul) poderá entrar pelo Mercado, mas, em regra, a maior parte segue concentrada numa rua mais estreita (Rua Olimpio Nicolau Rui Fernandes) indo desembocar entre a Câmara Municipal e a Caixa Geral de Depósitos, onde poderá inundar as casas comerciais que the barram o caminho no início da Rua da Sofia.

Num cenário destes, a deposição de materiais acontece imediatamente com a perda de declive, mas, apesar da dispersão, é natural que a maior parte da água se dirija para a Praça 8 de Maio, em virtude do plano inferior que lhe é oferecido pelas diversas ruas da chamada "baixinha" que aí começam (rua Direita, rua da Moeda, rua da Louça e Rua do Corvo). Até ao actual arranjo urbanístico da Praça 8 de Maio, já a água pouco aproveitava a Rua da Sofia. Virava preferencialmente para sul, seguindo o declive suave em direcção a essas ruas, podendo também

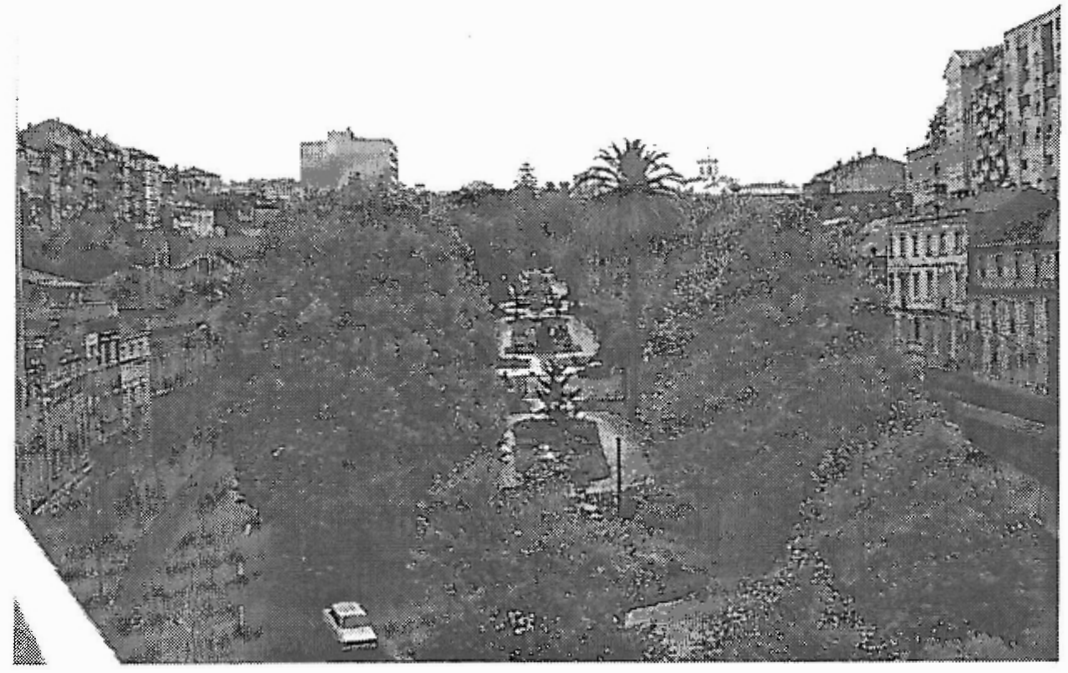


inundar a Igreja de Santa Cruz, então separada da metade baixa da Praça pela parte terminal da Rua Visconde da Luz, mais alta. Às vezes passava por cima, saltando os dois degraus protectores para depois descer as escadas (sete degraus), mas quase sempre passava por baixo, através do sistema de vasos comunicantes que the era dado pelos esgotos locais.

O Largo que recentemente se construiu não só permite uma descida mais rápida das águas, através da rampa de acesso e da queda vertical que esta oferece para oeste, como facilita a sua entrada na Igreja em virtude do declive suave criado mesmo a apontar para a porta, agora colocada no mesmo plano da Praça, apesar de ligeiramente protegida também por dois degraus.

O risco de inundação na área da Igreja de Santa Cruz, na Praça 8 de Maio, é, portanto, fácil de compreendercom os dados climáticos e com as características topográficas e urbanísticas desta parte da cidade. E se, no passado, já se tinham verificado vários casos de crise grave durante chuvadas fortes muito concentradas no tempo e até no espaço ${ }^{(3)}$, no presente, após as obras, e apesar do grande colector entretanto construido, alguma coisa já aconteceu também.

O caso mais recente verificou-se ao princípio da noite de 15 de Julho de 1997 - "A Praça 8 de Maio 'virou lago' e a água também não poupou a Igreja de Santa Cruz" dizia o Diário de Coimbra do dia seguinte (16 de Julho de 1997,p.3). Na edição de 17, o mesmo jornal informava que, no dia 15 , entre as 20 e as 21 horas, se registaram "em Coimbra 24 litros por metro quadrado de precipitação, o maior valor registado em Julho, numa hora, pelo Instituto Geofísico de Coimbra"; acrescentava ainda que "em meia hora caíram 23,6 litros /metro quadrado" (p. 4).

Com a ocorrência desta (felizmente pequena) inundação, deixou de ser puramente académico o problema de saber se, ainda hoje, com a rede de esgotos existente, se poderá falar de risco de inundação neste ponto da cidade. Em função do que se observou, ninguém poderá garantir o bom funcionamento das sarjetas em pleno Verão, mas muito especialmente no Outono quando, além das pedras e das areias, existem folhas disponíveis para as entupir; tal como ninguém poderá garantir que, mesmo com sarjetàs limpas, bem dimensionadas e de design correcto, a água, sendo muita em pouco tempo e deslocando-se tão depressa, se venha a perder toda na circulação subterrânea que lhe é oferecida. Do mesmo modo, ninguém poderá garantir que o Mondego, por muito controlado que esteja (F. REBELO, 1995 b), não volte a criar problemas na área urbana, em tempo de cheia.

(3) Uma fotografia da água a corrervertiginosamente por esta rua foi publicada pelo Dr. Mário Nunes (M. NUNES, 1990, p. 221) e corresponde a "uma bátega de água de enormes proporções" ocorrida em 1958.

\section{A bacia de recepção da Solum}

Outro caso de estudo pode ainda ser apresentado em Coimbra. Trata-se da drenagem do sector norte e nordeste do meandro abandonado do Mondego, vulgarmente dito meandro da Arregaça, na parte oriental da cidade (F. REBELO, 1985, p. 197-198). As características de pequena torrente são aqui menos marcadas, mas, mesmo assim, pode desenhar-se uma larga bacia de recepção (fig. 7) com várias linhas de água descendo do relevo envolvente (de altitudes próximas dos 160-170 metros, num caso atingindo os 186) ou mesmo da própria vertente côncava do meandro (de altitudes inferiores, mas que num caso atingem os 162 metros) para convergirem num relativamente estreito canal de escoamento encaixado no antigo leito do Mondego a que se chama a ribeira (ou vala) da Arregaça. A circularidade da bacia de recepção (praticamente $2 \mathrm{~km}$ por $2 \mathrm{~km}$ ) pode considerar-se perfeita para uma resposta às chuvas intensas com a colocação rápida das águas no início do canal de escoamento.

$\mathrm{O}$ crescimento da cidade para o antigo meandro verificou-se a partir dos anos 50. Surgiram ruas e progressivamente o escoamento natural das águas em tempo de chuva, na altura já muito difícil, passou a fazer-se em grande parte por circulação artificial, subterrânea.

Na verdade, foi-se verificando uma certa coexistência entre esse tipo de circulação e a circulação subaérea do escoamento pluvial. Ainda hoje isto se pode observar - há uma linha de água que corre quase paralela a uma avenida (Avenida Elísio de Moura) e que de repente é canalizada passando a seguir por baixo dela; até ao passado mês de Julho de 1997, reaparecia, umas centenas de metros adiante, como pequeno e sujo ribeiro, para, menos de uma centena de metros à frente, voltar a percurso subterrâneo; mais adiante, tornava a reaparecer por uma vintena de metros e de novo voltava à canalização subterrânea. Escusado será dizer que esta linha de água era responsável por uma parte significativa das inundações nas ruas do mais populoso e mais motorizado bairro de Coimbra - a Solum (N. GANHO, L. LOURENÇO e F. REBELO, 1992).

Todavia, a maior parte da água que origina as numerosas inundações aí verificadas, sempre que as chuvas são intensas, vem directamente daquela avenida, que intercepta toda a escorrência da vertente da margem direita da linha de água. Por motivos diversos, a circulação subterrânea nem sempre funciona bem e a essa água acresce a que vem doutras ruas e de outras linhas de água próximas, mais ou menos desorganizadas pela urbanização, como são exemplo recente as que sofreram com o traçado da Circular Interna desde os Olivais até à Solum.

De montante para jusante, na bacia de recepção da ribeira dita da Arregaça, quando ocorrem chuvas 


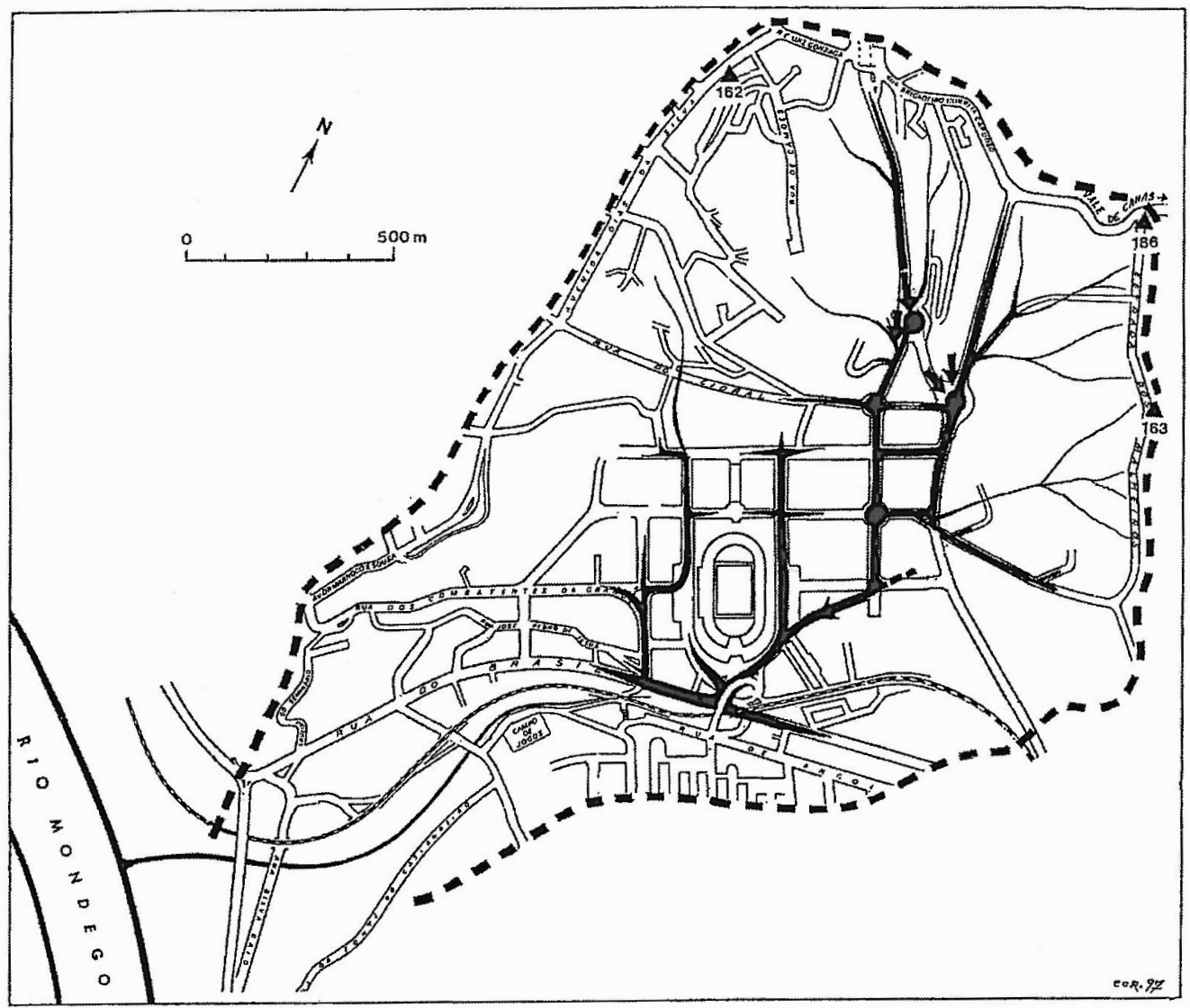

Fig. 7 - Coimbra - Bacia de recepção da ribeira da Arregaça. A negro representam-se os percursos da água por várias ruas da Solum até à Rua do Brasil, onde se concentra.

intensas, é inevitável uma forte deposição de calhaus e areias na rotunda onde desemboca a Rua Gago Coutinho, mas também a Rua do Cidral (hoje Rua Miguel Torga), e principalmente o prolongamento para norte da Rua Carolina Michaelis, que funciona como ligação rápida àquela Circular. Na Rua Gago Coutinho, entre esta rotunda, a Oeste, e a Avenida Elísio de Moura, a Leste, tem havido, por vezes, inundações importantes na Escola Eugénio de Castro, construida exactamente num fundo de vale onde antes se juntavam duas linhas de água desta complexa bacia de recepção.

Claro que há outras linhas de água que desaparecem nas canalizações subterrâneas. Como há, também, algumas outras que ainda funcionam naturalmente nas suas secções mais a montante. Sem dúvida que, em termos de inundações rápidas, tudo seria melhor se não estivéssemos numa área em constante evolução do ponto de vista urbanístico.

Já há mais de dez anos, verificámos que a montante e ao lado da referida Escola se formaram importantes ravinamentos após o arranque de toda a vegetação, numa vertente de declives entre 8 e $16 \%$, onde predominam depósitos superficiais de fraca coesão e formações gresoconglomeráticas de cor vermelha do Triássico, por vezes muito alteradas, também de fraca coesão. Sempre que ocorria uma forte chuvada, as ravinas funcionavam transportando grandes quantidades de argilas, areias e calhaus para as ruas e pracetas próximas, destruindo frequentemente partes do asfalto, passeios e até muros de jardins. Jogando com mais casos na área de Coimbra, constatámos então que a destruição do coberto vegetal em vertentes de declives médios sobre aqueles tipos de materiais rochosos (ou outros igualmente de fraca coesão), quando feita muito antes do início das obras de construção das habitações planeadas deixava tempo suficiente para que ocorressem chuvas intensas e se formassem ravinamentos (F. REBELO, 1982 e 1990).

Numa situação de crise forte, como a que aconteceu quando das chuvas intensas de 21-22 de Dezembro de 1989 ("93,1 mm de precipitação em menos de 24 horas", com um máximo horário de $23 \mathrm{~mm}$, entre as 3 e as 4 do dia 21), além do funcionamento das ravinas, verificou-se a ocorrência de diversos desabamentos, deslizamentos e solifluxões que também forneceram grandes quantidades de argilas, areias e calhaus (N. GANHO, L. LOURENÇO e F. REBELO, 1992). 
Todos estes processos têm sido responsáveis pelos materiais que, na sequência de chuvas intensas, vêm entulhar, antes de mais, as sarjetas (e talvez até os colectores de águas pluviais), e, depois, a referida rotunda, mas também pelos que, em regra de menor dimensão, ainda chegam a uma outra rotunda, duas centenas de metros adiante (rotunda da Rua Gen. Humberto Delgado) e aos quais se juntam os que são transportados pela água proveniente da Avenida Elísio de Moura (fot. 6). A partir daqui, a água, transportando muito menos carga sólida, embora ainda lamacenta, vai recuperar velocidade, graças ao declive da Rua Carolina Micaelis, mas também ao engrossar do caudal com aquela água que se lhe junta das chuvas intensas originava sempre inundações e continuará certamente a originá-las.

Estas inundações da Rua do Brasil são as mais conhecidas da cidade de Coimbra. Todas as casas antigas (e até algumas recentes) têm protecções nas portas (fot. 7), algumas, fixas, em cimento, outras, móveis, do tipo guilhotina, em madeira ou em ferro, com tamanhos entre $30 \mathrm{~cm}$ e quase um metro, à semelhança das que se vêem na "baixinha", onde correspondem mais a uma reminiscência das cheias do Mondego do que de inundações locais.

O perfil da Rua do Brasil mostra uma ligeira descida desde a passagem de nível da linha Coimbra-Lousã, atingindo a cota mais baixa nas proximidades

Fot. 6 - Coimbra - Solum: trabalhos de limpeza da rotunda da Rua Gen. Humberto Delgado após as inundaçōes de

21 de Dezembro de 1989.

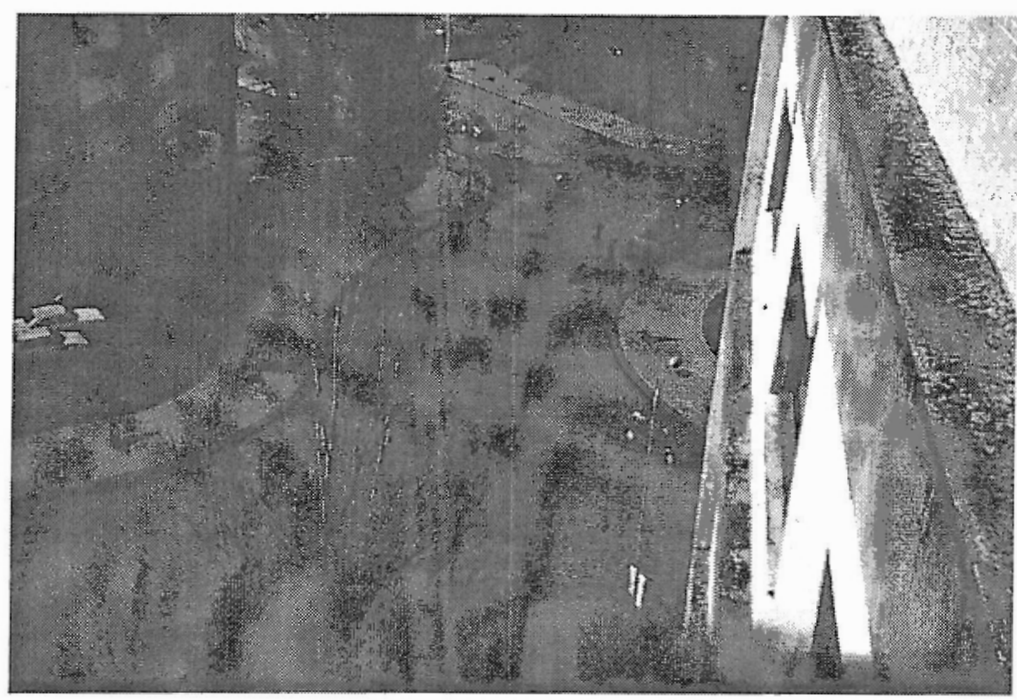

vinda da Avenida e que às vezes ocupa toda a faixa derodagem da Rua Gen. Humberto Delgado obrigando os automóveis a circular pelos passeios... Numa primeira fase, parte desta água caía na vala por onde correria normalmente antes da urbanização; mas a vala, que inicialmente só transbordaria uma centena de metros adiante, perto do Estádio Municipal, depressa transbordava em virtude da canalização (pouco eficiente para estas circunstâncias). Por isso seria de esperar o seu transbordamento na então meia-praceta onde lhe chegava a água do escoamento superficial - a inundação em frente ao Centro Comercial Girassolum, embora sem gravidade, verificava-se quase sempre nessas situações. De qualquer modo, transbordando, como no passado recente, ou não transbordando, como a partir de agora, se o seu percurso inteiramente subterrâneo fôr eficaz, parte dessa água, com água vinda de outras áreas da bacia de recepção, continuará a seguir pelas ruas, sem sequer entrar nas sarjetas, até à saída sul do Estádio e descerá até à Rua do Brasil. Aqui, na área do cruzamento (vulgarmente chamado dos semáforos) com a Rua dos Combatentes, ela também fornecedora de caudais razoáveis, a água do referido cruzamento dos semáforos voltando a subir mais adiante. Esta cota mais baixa corresponde exactamente à área de concentração da drenagem da bacia de recepção da ribeira da Arregaça. Imediatamente a leste da passagem de nível também se encontra uma área deprimida na mesma rua, onde de igual modo se concentram águas em momentos de chuvas intensas; trata-se do efeito de barragem provocado por um ligeiro levantamento da rua no local exacto da passagem de nível.

$\mathrm{Na}$ atrás referida situação de chuva ao fim da tarde de 15 de Julho de 1997, uma vez mais se verificaram inundações em caves e pisos térreos desta rua, tal como vários automóveis ficaram bloqueados pelas águas. O Diário de Coimbra (17 de Julho de 1997, p. 4) noticiou que "a circulação esteve interrompida durante cerca de 45 minutos", não só neste local, mas também numa avenida nova (Avenida Fernando Namora), localizada a montante, no contexto da mesma bacia de recepção, que veio cortar a drenagem natural de pequenas linhas convergindo para a ribeira da Arregaça. No dia seguinte, o mesmo jornal dava notícia de obras previstas para melhoria da 


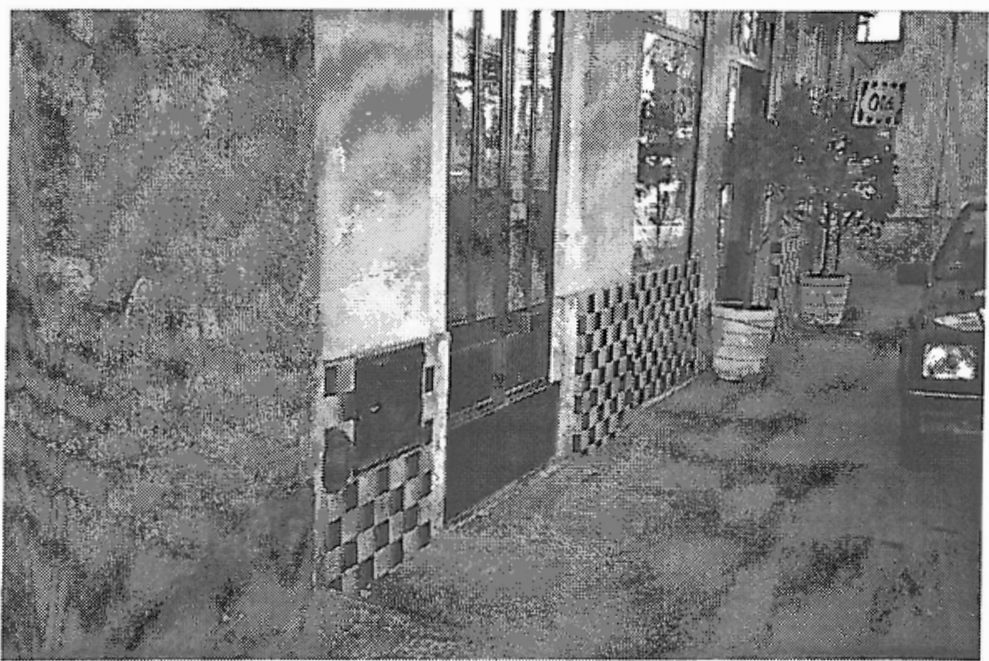

Fot. 7 - Coimbra - Rua do Brasil: protecção contra inundações.

canalização subterrânea na área próxima do Estádio; dois meses depois as obras estavam quase feitas - a vala acabou, embora ainda se note uma ligeira depressão na área por onde passava, o traçado rectilínio da canalização poderá ser um elemento positivo, mas temos dúvidas quanto ao seu redimensionamento ${ }^{(4)}$; espera-se que não seja esquecido o "design" das sarjetas e a calendarização rígida dos trabalhos de manutenção, tanto mais que o aplanamento da área, quase no centro geográfico da bacia de recepção e antes da concentração de águas no canal de escoamento, é um factor favorável à perda de velocidade das águas e à deposição de materiais. O risco de pequenas inundações em frente ao Centro Comercial Girassolum ainda continuará com certa importância, só podendo vir a diminuir com o avanço da urbanização nas secções mais a montante da bacia; o risco de inundações razoáveis na Rua do Brasil não parece vir a alterar-se muito com as obras em curso na Solum - há outras ruas que, em caso de chuvas intensas, continuarão a funcionar como linhas de água da bacia de recepção.

\section{Conclusão}

Embora a escalas diferentes, a análise, primeiro, dos casos verdadeiramente catastróficos de Lisboa, Funchal e Povoação e, agora, destes três casos críticos na área urbana de Coimbra mostra que o risco de

(4) A simples observação dos trabalhos feitos em Julho de 1997 frente ao Centro Comercial Girassolumpermitiu concluir que a canalização colocada, seguindo um traçado inteiramente novo, não terá metade da capacidade que tinha a velha vala agora substituida e que, mesmo assim, tantas vezes transbordava. A menos que sejam feitas outras canalizações paralelas, esta não irá resolver o problema das inundaçōes locais e, muito provavelmente, os futuros habitantes dos novos artuamentos poderão ver saltar as tampas do saneamento, tal como nas proximidades do Estádio tem sido possível ver quando de chuvadas intensas (há quem se refira a saltos de dois metros de altura...) inundações locais rápidas se vai mantendo apesar dos trabalhos de engenharia que às vezes se fazem para os ultrapassar.

No caso de Coimbra, onde, em certas circunstâncias, algumas ruas podem funcionar como elementos constituintes de pequenas torrentes, as situações de crise são mais frequentes nas áreas ainda não estabilizadas em termos de evolução urbanística; dir-se-á que, aí, o risco de inundação rápida é maior atendendo à quantidade de material disponível para transporte pelas águas de escorrência. Quando habituadas a conviver com a crise, as populações procuram o seu bem-estar com defesas contra a invasão da água; em regra, essas populações actuam apenas quando o perigo se instala, ou seja, quando na sequência de vários dias de chuva há receio da ocorrência de aguaceiros fortes ou, mesmo e apenas, quando a chuva começa a cair com mais intensidade. Muitas vezes, porém, a crise surpreende ou porque já não se esperava que acontecesse devido a obras recentes, ou porque não se tinha consciência do risco e não se atendeu aos indicadores de perigo. Será, então, o momento, primeiro, da actuação dos bombeiros e, depois, das companhias de seguros, sempre sob um coro de protestos contra os autarcas.

No caso das grandes catástrofes de Lisboa, Funchal e Povoação a escala é diferente. Trata-se igualmente do funcionamento de torrentes na sequência de chuvas intensas, mas umas e outras são de dimensões bem superiores às dos pequenos casos de Coimbra. As altitudes envolvidas nas bacias de recepção são mais importantes; à partida, para o mesmo tipo de risco climático, o agravamento proveniente da altitude é maior para o Funchal, do que para a Povoação ou, por maioria de razão, para a região de Lisboa; para vulnerabilidades semelhantes, o risco de ocorrência de grandes catástrofes será, portanto, superior no Funchal. No entanto, as características hidrográficas 
das torrentes da Povoação poderão compensar o efeito de uma altitude inferior às do Funchal nas suas bacias de recepção - ao drenarem uma grande parte da área da caldeira do aparelho vulcânico do mesmo nome e ao juntarem-se num só cone de dejecção, as ribeiras apresentam uma circularidade favorável a respostas rápidas às chuvas intensas; com as vulnerabilidades existentes, o risco de ocorrência de catástrofes é grande também.

No caso de Lisboa, a possibilidade de um certo agravamento do risco climático em função das altitudes, embora existente na bacia do Rio Trancão, não é significativo e no caso acompanhado na área do Estoril o problema nem sequer se põe; a resposta rápida do Trancão, graças a uma razoável circularidade da sua bacia, é, sem dúvida, um factor favorável às inundações rápidas, mas não parece suficiente para justificar, só por si, um risco elevado; o risco de inundação aumentará, sem dúvida, pelo facto de desaguar no Tejo numa situação de digitação de planície aluvial. Este facto poderá criar dificuldades a algumas outras ribeiras da área de Lisboa no momento de escoarem as suas águas de cheia. Todavia, as crises de dimensão catastrófica de 1967 e 1983 terão de ser explicadas mais pelas características da ocupaçãohumana do que pelas características naturais.

A noção de risco resulta do somatório da eventualidade de actuação das componentes naturais com as vulnerabilidades. Por isso, o risco da ocorrência de inundações rápidas de características catastróficas não parece hoje ser tão grande na área de Lisboa como na própria cidade do Funchal ou na vila da Povoação, mas, no que respeita às povoações ribeirinhas ao rio Trancão, atendendo ao tamanho da bacia e à presença do Tejo, é, naturalmente, superior à das ruas e bairros apresentados em Coimbra.

No entanto, os casos estudados em Coimbra, salvaguardadas as devidas proporções, podem trazer uma pequena lição para os outros. Algumas ruas funcionam como verdadeiros leitos de canais componentes de bacias de recepção ou canais de escoamento, quando não como elementos de cones de dejecção. Após as crises, depois da actuação dos bombeiros, vêm os serviços camarários limpar as ruas - às vezes são toneladas de calhaus, areia e argila que enchem várias camionetas em trabalhos que demoram horas ou dias. O mesmo se faz em Lisboa, no Funchal, na Povoação ou em quaisquer outros espaços urbanos que sofram inundações. Trata-se de repor uma situação para permitir o trânsito normal das viaturas. Torna-se necessário que algo de semelhante se faça nos leitos das torrentes e não só nas ruas que elas inundam - a deposição nos canais, por um lado, tira-lhes capacidade de escoamento para novas ocorrências, ou seja, primeiro, para uma mesma quantidade de água a escoar, transbordarão mais cedo, depois, nem serả precisa a mesma quantidade para transbordarem; por outro lado, as águas em movimento rápido terão muito mais material disponível para transportar, mesmo antes de receberem os achegos laterais provenientes de movimentos em massa nas vertentes.

\section{BIBLIOGRAFIA}

AMARAL, Ilídio do (1968) - "As inundações de 25/26 de Novembro de 1967 na região de Lisboa”. Finisterra, Lisboa, 3(5), p. 79-84.

BLAIKIE, Piers, CANNON, Terry, DAVIS, Ian and WISNER, Ben (1994) - At Risk. Natural hazards, people's vulnerability and disasters. London, Routledge, 284 p.

ESTIENNE, Pierre et GODARD, Alain (1970) - Climatologie. Paris, Armand Colin, $365 \mathrm{p}$.

FAUGĖRES, Lucien (1990) - "La dimension des faits et la théorie du risque". Le Risque et la Crise, éd. L. FAUGÈrES, P. VASARHELYI et C. VILLAIN-GANDOSSI, Malta, Foundation for International Studies, p. 31-60.

FERREIRA, Denise de Brum (1985) - "Les dépressions convectives du bassin atlantique nord subtropical oriental". Finisterra, Lisboa, 20 (39), p. 25-45.

FERREIRA, Maria Fernanda (1995) - Recherche dans le domaine des risques majeurs - le cas des inondations aux illes de Madère. Rapport, DESS Gestion Globale des Risques et des Crises, Université Paris I - Panthēon-Sorbonne (polic. inédito)

GANHO, Nuno, LOURENÇO, Luciano e REBELO, Fernando (1992) - "Importância da Climatologia e da Geomorfologia no Planeamento Urbano. Análise de um caso concreto na parte oriental da cidade de Coimbra". Cadernos de Geografia, Coimbra, 11, p. 75-85.

JALHAY, Eugénio e PAÇO, Afonso do (1941) - "A gruta II da necrópole de Alapraia". Anais da Academia Portuguesa de História, 4, p. 103-140.

MARGARIDO, Ana Paula (1987) - "A morfologia urbana da 'Alta' de Coimbra - ensaio sobre o traçado da malha e sua evolução". Cadernos de Geografia, 6, p. 43-69.

MARGARIDO, Ana Paula (1988) - "A morfologia urbana da 'Alta' de Coimbra - suas condicionantes". Alta de Coimbra, HistóriaArte-Tradição, Coimbra, GAAC e Livraria Minerva, 355 p.

MARTINS, Alfredo Fernandes (1940) - O Esforço do Homem na Bacia do Mondego. Coimbra, ed. Autor, 299 p.

MARTINS, Alfredo Fernandes (1983) - "Esta Coimbra... -alguns apontamentos para uma palestra". Cadernos de Geografia, 1, p. 35-78.

NOVA, Elisa Vila(1996) - Educarpara a Proteç̧ăo Civil. Projectos para a área-escola e actividades de complemento curricular. Lisboa, Texto Editora, 1996, 159 p. 
NUNES, Mário (1990) - Coimbra - Imagens do Passado, 19401960. Coimbra, Livraria Minerva, $223 \mathrm{p}$.

PÉGUY, Ch (1970) - Précis de Climatologie. Paris, Masson, 468 p.

QUINTAL, Raimundo (1994) - Veredas e Levadas da Madeira. Funchal, Região Autónoma da Madeira, Secretaria Regional da Educação, 215 p.

QUINTAL, Raimundo e VIEIRA, Maria José (1985) - Ilha da Madeira. Esboço de Geografia Física. Funchal, Região Autónoma da Madeira, Secretaria Regional do Turismo e Cultura, $89 \mathrm{p}$.

REBELO, Fernando (1982) - "Considerações metodológicas sobre o estudo dos ravinamentos". Comunicaçōes, II Colóquio Ibérico de Geografia, Lisboa, 1980, vol. I, p. 339-350.

REBELO, Fernando (1985) - "Nota sobre o conhecimento geomorfológico da área de Coimbra (Portugal)". Memórias e Notícias, Publ. Museu e Lab. Mineral. e Geol., Universidade de Coimbra, 100, p. 193-202.

REBELO, Fernando (1990) - "Geografia Física e Ambiente. Temas e Problemas. Alguns casos concretos escolhidos em Portugal". Cadernos de Geografia, Coimbra, 9, p. 85-95.

REBELO, Fernando (1994) - "Do ordenamento do território à gestão dos riscos naturais. A importância da Geografia Física salientada através de casos de estudo seleccionados em Portugal". Territorium, Coimbra, 1, p. 7-15.

REBELO, Fernando (1995a) - "Os conceitos de risco, perigo e crise e a sua aplicação ao estudo dos grandes incêndios florestais". Biblos, Coimbra, 71, p. 511-527.

REBELO, Fernando (1995b) - "Hommes et érosion dans le centre et lenord du Portugal. Le cas du bassin du Mondego". Territorium, Coimbra, 2, p. 5-10.

REBELO, Fernando e RAPOSO, António Guilherme B. (1988) "As inundações de 2 de Setembro de 1986 na Povoação e no Faial da Terra (S. Miguel - Açores)"'. Cadernos de Geografia, Coimbra, 7, p. 169-179.

ROCHA, João Soromenho (1995) - "Prevenção de inundações e reabilitação de edifícios em zonas inundáveis". Territorium, Coimbra, 2, p. 11-20.

SILVA, José Manuel Azevedo e (1995) - A Madeira e a Construção do Mundo Atlântico (séculos XV-XVII). Funchal, Região Autónoma da Madeira, Secretaria Regional do Turismo e Cultura, CEHA, Memórias, 10, 2 vols, 1086 p.

VIERS, Georges (1968) - Eléments de Climatologie, Paris, Fernand Nathan, $224 \mathrm{p}$. 
